\title{
The Impact of Board Structure on Bank Performance: Evidence from European Banks
}

\author{
Shamini Abeysirigunawardana ${ }^{1}$
}

\begin{abstract}
This study aims to investigate whether board characteristics of banking institutions affect their performance, using a panel data set comprising 45 banks and 270 bank-year observations in the European region over the period of 2010-2015. The study finds that there is a positive relationship between both the board size and the proportion of independent directors, and bank performance. Also, the study finds evidence that the gender diversity decreases bank performance. Interestingly, when it is tested for the presence of a non-linear relationship, the study finds an inverted U-shape relationship between both the board size and the proportion of independent directors, and the bank performance and a $U$-shape relationship between gender diversity and bank performance. The results show that the boards that are larger and not excessively independent are more effective in discharging their duties. Achieving the optimum mix of internal and external directors will result in the board becoming more efficient in their advisory and monitoring roles. Also, results shows that appointing female directors above a minimum threshold will improve bank performance, a finding that is consistent with the critical mass theory and supports the introduction of gender quotas as well. The findings of this study provide useful insights to policymakers in setting corporate governance regulations relating to board structures. The use of fixed effect estimation control for unobserved heterogeneity and the findings of the study are robust to alternative proxies of performance.
\end{abstract}

Key Words: Board Structure, Bank Performance, Corporate Governance

JEL Classification: G21, G28, G30, G32, G38

\footnotetext{
${ }^{1}$ The author currently serves as a Senior Assistant Director of the Department of Supervision of Non-Bank Financial Institutions at the Central Bank of Sri Lanka. Corresponding email: shamini@cbsl.lk. The author wishes to thank Professor Hisham Farag, Head of Department of Finance, University of Birmingham for the valuable advice and guidance throughout the period of completing the research. The views presented in this paper are those of the author and do not necessarily indicate the views of the Central Bank of Sri Lanka.
} 


\section{Introduction}

The governance structure of the financial institutions was largely criticised during the Global Financial Crisis (GFC) in 2008/09. It differs from the previous financial crises in which a large part of the blame was attributed to the loopholes in the risk management strategies and weak corporate governance structures within financial institutions. The introduction of the UK Combined Code of Corporate Governance in 2009, the Guidelines on Internal Governance issued by the European Banking Authority and the most recent introduction of the Green Paper of corporate governance in the United Kingdom (UK) show the importance given to corporate governance regulations by policy makers. In the governance structure, importance has been given to board characteristics such as board size, board composition and board diversity. Therefore, this study has focused on identifying the extent to which board characteristics affect bank performance by taking a sample of European banks during the post crisis period.

Failure of a bank costs an economy losses in trillions. All governments around the world conducted massive bailout packages during the crisis in which notable bailouts were the Royal Bank of Scotland and the Halifax Bank of Scotland in the United Kingdom. Similarly, European governments conducted massive bailouts that exceeded \$10 trillion (Mishkin, 2016). A well-governed bank is critical to the efficient allocation of resources of an entire economy, due the role it plays in financial intermediation, the payments system, liquidity creation, and maturity and denomination transformation (Fama, 1985).

Bank governance via the board is the most effective way of achieving good governance. According to Caprio and Levine (2002), the board of directors (BOD) are an important source of good governance, because dispersed shareholders and debt holders cannot impose effective governance in banks. The BOD act as the link between the firm's management and the other stakeholders and this is of utmost importance, as banks operate in highly regulated and complex business environments. Also, it is more relevant in banks rather than in nonbanks, since the fiduciary responsibility of banks extend well beyond the shareholders to depositors and regulators as well (Macey and O'Hara, 2003). The GFC in 2008 provides the opportunity to study how better-governed banks performed during the crisis.

In the post-crisis period, the Basel Committee on Banking Supervision in its consultative document "Corporate Governance Principles for Banks" (2015) has identified the importance of the BOD in achieving effective corporate governance. Moreover, the second pillar of the Basel II "Supervisory Review Process" identifies the board as an essential part of risk management. In the USA, the "Dodd-Frank Wall Street Reform and Consumer Protection Act" enacted after the financial crisis includes provisions related to corporate governance. In the UK, the Walker Review, in 2010, on the financial services sector, gave rise to the UK Corporate Governance Code (latest amendment in April 2016 and formally known as the 
Combined Code of Corporate Governance), which comprised five main principles of Leadership, Effectiveness, Accountability, Remuneration and Relationship with shareholders. Further, the Prudential Regulatory Authority operating under the Bank of England issued a supervisory statement "Corporate Governance: Board Responsibilities", which stipulate some requirements on the board structure for financial institutions. A half of the board (excluding chairman) should be independent non-executive directors (NED) (p. 7), a director who served the Board for more than 9 years deemed not to be independent and the need to separate the role of Chairman and CEO are few criteria stipulated for listed banks.

The existing literature that tests the corporate governance-financial performance relationship is inconclusive, especially the studies that focus on the financial sector. Therefore, this study aims to investigate the relationship between board structure and bank performance during the post crisis period using a recent dataset during the period of 2010-2015.This study focused on the association between the board structure and bank financial performance. Using a sample of 45 European banks comprised of 270 bank-year observations, the study aimed to identify the effect of board size, board composition and the gender diversity on the bank performance.

The findings of this study provide valuable insights to policy makers, and it is presumed that the results of this study are timely, due to the European Commission's increasing focus on improving corporate governance. At the first instance, the study finds that there is a positive relationship between both the board size and proportion of independent directors and bank performance. Also, the study finds evidence that gender diversity decreases bank performance. Interestingly, the study finds nonlinear relationships between board characteristics and bank performance when the quadratic term of the independent variable is controlled. Empirical evidence suggests that there is an inverted U-shape relationship between board size and bank performance, and the number ranges between 19-28 directors (Results differ based on the estimation method as well as the use of alternative proxies of performance). I.e. appointing additional directors beyond the above threshold will decrease bank performance. Also, regarding the proportion of independent directors, there is an inverted U-shape relationship and appointing a proportion of independent directors above 64\% will decrease the bank performance. It is important to have an appropriate mix, as banks benefit from directors with their firm specific knowledge given through advisory roles. Interestingly, the study finds that there is a U-shape relationship between the proportion of female directors and bank performance. At first instance, empirical evidence shows there is a negative correlation, but appointing female directors above a critical mass of $34 \%$ will increase bank performance. This finding is consistent with the critical mass theory of Kanter (1977), showing that it is important to appoint a certain threshold of female directors to the board to obtain the benefits of their diverse skills and abilities.

The remainder of the paper is structured as follows: Section 2 discusses the theoretical background of corporate governance and firm performance relationship followed by a literature review and research hypothesis. Section 3 presents an overview of the institutional 
background of banks in the European region and its corporate governance codes, Section 4 discuss the data and empirical model, Section 5 presents the empirical results, and finally, Section 6 summarises the study with a discussion of findings and areas for further research.

\section{Theoretical background and literature review}

\subsection{Theoretical background}

BODs of an organisation are entrusted with four functions: monitoring and controlling of the management, providing advice, monitoring compliance with the law and the creating a link between the firm and the external environment. (Mallin 2004; Monks \& Minow 2004). The general understanding is that the structure of the board will affect the way the board performs the above functions. Therefore, board structure components like board size, the proportion of independent directors and gender diversity of a board are assumed to be linked to the effectiveness of the board and thereby, affect towards the firm performance positively or negatively.

There is no single theory that describes the effect of corporate governance on firm performance. The existing literature is mainly focused on the empirical findings of the studies conducted in this regard. Following Carter, Simkins and Simpson (2003), Carter et al. (2010), Boone et al. (2007) and Farag and Mallin (2017) seven theories were drawn from the various disciplines to provide an insight into the relationship between board structure and performance, namely agency theory, resource dependency theory, human capital theory, contingency theory, social psychological theory, the scope of operation hypothesis and the critical mass theory.

Agency theory assumes that a higher proportion of independent directors will lead to better monitoring, which will be helpful to overcome the agency problem (Hillman and Dalziel, 2003). Therefore, it is important that boards should comprise an appropriate mix of internal and external directors with different backgrounds and experiences (Hillman and Dalziel, 2003; Adam and Ferreira, 2009). More diverse boards with members from different backgrounds will be more independent and thus provide a better monitoring role (Carter, Simkins \& Simpson, 2003; Carter et al., 2010). Further Adam and Ferreira (2009) found that female directors are more effective in relation to the monitoring function. Supporting the above view, Farag and Mallin (2017) and Carter et al. (2010) stated that female directors improve the monitoring role as well as lower the agency costs. However, agency theory is unable to provide a clear link between board diversity and financial performance (Carter, Simkins and Simpson, 2003; Carter et al., 2010).

Resource dependence theory is concerned with how organisational behaviour is affected by external resources the organisation utilises. As per Pfeffer and Salancik (2003) the board serves 
as the link between the organisation and external environment. These external linkages are capable of the providing resources such as information and expertise, the creation of communication channels and providing support of the important groups in the external environment (Pfeffer and Salancik, 2003). Hillman, Cannella, and Paetzold (2000) suggest that different types of directors (internal members, business experts, support specialists and community influential) will provide different benefits to the firms. Therefore, more diverse boards (with external members and gender and ethnic diversity) will provide more valuable resources for better firm performance. For example, female directors can bring forward new opinions and ideas that would not happen in homogeneous boards (Mateos de Cabo et al., 2011). Hence, the resource dependency theory provides convincing arguments in support of board diversity.

The above argument is also supported by the human capital theory, which states that a person's education, experience and skills would be beneficial to the organisation (Becker, 1964). Therefore, diversity among directors will result in them having different human capital, which will benefit the overall firm performance (Terjesen et al., 2009). Hillman et al. (2002) find that gender diversity, as well as ethnic diversity, give people different business expertise. For example, female African-American directors are less likely to be business experts than African-American male directors. Therefore, gender diversity will result in the unique human capital, which could either affect the financial performance of the firm positively or negatively. (Carter et al., 2010)

Contingency theory suggests that the impact of board diversity on firm performance will be affected by the external and internal environment in which the firm operates (Carter et al., 2010). Gender diversity will benefit some organisations and not others, and it will have a different impact during different time periods (Adam and Ferreira, 2009). Consistent with the above argument, a study conducted using a sample of several firms over a specific period gave no effect as the positive and negative effects of diversity offset each other (Carter et al., 2010).

Boone et al. (2007) in their study attempted to find out the forces that drive the board size and composition. Following the work of Fama and Jensen (1983) and Coles et al. (2008), Boone et al. (2007) presented the scope of operation hypothesis stating that the Board structure is driven by the scope and complexity of firm operations. Supporting the above hypothesis, they found that firm size, firm age and number of business segments have a positive effect on the number of directors and proportion of independent directors. It implies that when firms grow, the board size as well as the proportion of independent directors also grow, providing increased net benefits of monitoring.

The social psychological theory of minority status poses an opposing argument to the favourable view on the inclusion of female directors in corporate boards. According to Westphal and Milton (2000), the above concept states that the majority status group has a more powerful influence on the decision-making process and the minority group, i.e., the 
women, in this case, will not have enough power to exert influence. As a result, the benefit of having a diverse board will not be realised.

Supporting the above, the critical mass theory of Kanter (1977) stated that until a certain threshold or a "critical mass" is appointed to the board, the abilities and the skills a female director brings to the board is undervalued. The empirical study conducted by Joecks, Pull and Vetter (2013) confirmed the above findings and the above theory could be linked to the reason for the introduction of gender quotas as well.

The existing theoretical underpinnings do not give a clear link between the nature of the relationship. Hence, the board size and the composition of the board (proportion of external directors and female directors) may have both positive and negative effects on firm performance. The next section will discuss the empirical findings of the literature on the topic.

\subsection{Literature review and research hypothesis}

\subsubsection{Board structure and performance in the banking industry}

The structure of the BOD and firm financial performance is a widely-investigated topic in business literature which goes the back to the early 1990s (Adam and Mehran, 2012). However, most of the existing literature that focused on testing the above relationship overlooked banking institutions (Adam and Mehran, 2012). The studies that focused on the relationship between board structure and bank performance have been conducted by Andres \& Vallelado (2008), Adam and Mehran (2012), Pathan and Faff (2013), O'Sullivan, Mamun and Hassan (2015) and Salim, Arjomandi and Seufert (2016). Most of the above studies that focused on the banking sector used sample data of the US banks (E.g. studies conducted by Andres \& Vallelado, 2008; Pathan, 2009; Adam \& Mehran, 2012; Pathan and Faff, 2013; and O'Sullivan, Mamun \& Hassan, 2015). The impact of board structure on European banks has not been a study area with greater attention. According to the knowledge of the researcher, studies conducted by Farag and Mallin (2017), Mateos de Cabo, Gimeno and Escot (2011) and Mateos de Cabo et al. (2012) used European banks as the sample in their studies. But there has been no study conducted to test the impact of bank performance of European banks, which capture board structure variables such as board size, board independence and gender diversity. Therefore, it is important to carry out this study to fill the existing gap in the current literature.

\subsubsection{Board size and performance}

The most common finding in the existing literature is that there is a negative relation between board size and firm performance (Yermach, 1996; Eisenberg et al., 1998 and Hermalin and Weisbach, 2003). Jensen (1993) argued that as the board became larger, boards became less effective in monitoring and management, and faced increased decision-making time due to the issues of communication and coordination as well as free rider problems. Further, the directors in large boards have limited time expressing their opinion at the Board meetings (Liptin and 
Lorsch, 1992). On the contrary Dalton et al. (1999) argued that large boards are an added advantage to the firms as they are a combined source of expertise and resources. In a study focused on non- financial firms, Coles et al. (2008) found that the relationship between board size and Tobin Q is U-shaped. That is, in more complex firms, performance increases with larger boards. They argue that, advisory benefits of larger boards outweigh the cost of maintaining larger boards, especially in the case of complex firms. They further comment that most existing literature found a negative relation in the sample of non-financial firms because most of the samples consisted of simple boards. The above finding is consistent with the scope of operations hypothesis by Boone et al. (2007) which stated that for larger and complex firms the benefits of the monitoring and advisory role of directors are higher than the cost of maintaining larger boards, and hence provided an argument for having larger boards.

The banking sector results are mixed as some studies found a positive relation, inverse relation as well as a concave relation. E.g. Adam and Mehran (2012) conducted a study using 35 listed bank holding companies (BHC) in the USA and found that board size is positively related to the performance. A similar study conducted by O’Sullivan, Mamun and Hassan (2015) using the largest $150 \mathrm{BHC}$ in the US also found that board size, CEO tenure and board tenure enhance the bank performance in normal times, but during the crisis period board size had a negative effect on Tobin $Q$ ratio. The findings of the above studies are consistent with the findings of Coles et al. (2008) and Boone et al. (2007); that due to the complexity of banks, the benefits of large boards will outweigh the costs of maintaining large boards. Adam and Mehran (2012) presented two reasons for having larger boards. The bank board grows after a merger and acquisition (M\&A) to accommodate additional directors from the target company. Secondly, many complex organisations have many subsidiaries within their own boards. To facilitate coordination within the group, it is important to have representatives of the subsidiary companies on the bank boards. As a result, having larger boards due to the M\&A activity and to facilitate the complex organisational structure suggests that the effect of the board size on the bank performance may be positive. On the contrary, the study conducted by Pathan and Faff (2013) using a sample of USA BHC's, during the period 1997-2011 found that, board size decreases the bank performance. Liang, Xu and Jiraporn (2013) also yielded similar results using a sample of 50 largest Chinese banks that board size has a significantly negative impact on bank performance.

Based on the above discussion, the researcher followed the arguments made by Adam and Mehran (2012) and Coles et al. (2008) and presumed that larger boards will benefit the banks due to the complexity of the banks. The first hypothesis related to board size is as follows;

\section{$\mathrm{H}_{1}$ : There is a positive relationship between board size and bank performance.}

Even though the researcher hypothesizes that board size positively relates to performance, there is a trade-off between advantages of larger boards (benefits of advisory and monitoring roles) and disadvantages (coordination, control and decision-making problems). Similar to the 
findings of Coles et al. (2008), Andres and Vallelado (2008) found an inverted U-shaped relation between bank performance and board size using a sample of 69 large commercial banks from six OECD countries. Findings show that boards that are not excessively large affect performance positively, as when the number of directors reaches 19, Tobin's Q starts to diminish. The findings challenged the dominant belief of "one-size-fits-all" in boards, and this is particularly true, for the banking industry operates in a complex and uncertain environment (Andres \& Vallelado, 2008). As discussed above, this study is interested in finding whether there is a nonlinear relationship between board size and bank performance. Therefore, the second hypothesis is formulated as follows;

$\mathrm{H}_{2}$ : There is a nonlinear relationship between board size and the bank performance.

\subsubsection{Board independence and performance}

According to Adam and Ferreira (2007), BODs play a dual role as advisors as well as the role of monitoring of the management. As per the theoretical governance literature, the optimal board composition should try to achieve a balance between advising and monitoring needs. Independent directors are considered as better monitors of managers due to their willingness to maintain their reputation in the Directorship market (Fama \& Jensen, 1983). Independent directors are tougher monitors (Hermalin \& Weisbach, 2003) as well as they can offer valuable advice from different perspectives. The role of external directors is more important in complex firms, which need better monitoring and advice due to the complex business environment.

Coles et al. (2008), using a sample of non-financial firms, found that the proportion of independent directors are positively related measures of firm complexity and the above finding is consistent with the scope of operation hypothesis presented by Boone et al (2007) as well. On the other hand, they found that for R\&D-intensive firms, for which the firm-specific knowledge of internal directors is relatively important, a higher fraction of insiders on the board is important. Therefore, the potential disadvantage of external directors is that they lack firm specific information which may be problematic for their effective advisory role (Adam and Ferreira, 2007).

What does hold true for the banking institutions? The corporate governance mechanism in banks plays a special role due to the unique functions of the banking institutions. Studies on the corporate governance of the banking industry acknowledge the problems regarding complexity and regulation (Andres \& Vallelado, 2008). The complexity of a bank arises due to financial engineering not being transparent, complicated financial statements, underestimated investment risk, overstated quality of loans etc. (Levine, 2004). To manage the complexity, it requires a board who can monitor managers effectively and be capable of giving valuable advice with firm-specific knowledge. Regulations also plays an important role in financial institutions. There might be restrictions imposed on ownership structures, board structures and as a part of their supervision regulators monitor the bank boards as well (Andres \& Vallelado, 2008). 
As mentioned earlier external directors are better monitors of the management, but an excessive proportion of independent directors will reduce the effectiveness of the advisory role of the board as it prevents executive directors with firm specific knowledge to join the board (Adam and Ferreira, 2007). Therefore, there is a trade-off between pros and cons of the proportion of outside directors.

Empirical studies conducted on banks showed mixed results relating to the relationship between independent directors and the firm performance. The findings of existing studies show a positive, inverse, concave relationship as well as no relationship at all. Some studies show a positive relationship as they can improve earnings quality (Mishra \& Nielsen, 2000), lower the cost of debt financing (Anderson et al., 2004) and improve credit rating (AshbauhSkaife et al.,2006). Adam and Mehran (2012) found board independence is not related to performance, as measured by Tobin Q. Andres \& Vallelado (2008) found an inverted Ushaped relation between the proportion of outsiders and firm performance, i.e. putting more external directors creates more firm value, but when reaching a higher proportion of external directors, Tobin Q starts to diminish. It is important to identify the optimal mix of executive and non-executive directors to create more value for the firm than excessively independent boards. To be efficient boards also should include executive directors, whose insider knowledge is as important as a non-executive director's ability.

According to Pathan and Faff (2013) banks with more independent directors perform worse. Due to the high information asymmetry, complexity and the highly-regulated environment of banks, the addition of more independent directors does not reflect an improved performance. This finding is consistent with the argument of Fama and Jensen (1983) that complex firms with high information asymmetry operate in an uncertain environment, and will benefit from more inside directors with firm specific knowledge. Supporting the above argument, Duchin et al. (2010) found a positive relation between board independence and firm performance in non-bank firms with low information asymmetry and less complexity. Alternatively, Subrahmanyam et al. (1997) argued that the intense regulation and severe penalties discouraged qualified and experienced directors from serving on bank boards. Therefore, the addition of new independent directors does not create value. Adam and Ferreira (2007) in their study of "Theory of friendly boards" stated that banks with high information asymmetry should not rely on monitoring by independent directors.

Therefore, after considering the above arguments the researcher concluded that independent directors and bank performance have a positive relationship since independent directors are better monitors of management. To test the above-expected relationship the following hypothesis was developed:

$\mathrm{H}_{3}$ : There is a positive relationship between the proportion of independent directors and the bank performance. 
As discussed above, since excessively independent boards are not beneficial it is important to find out the optimum mix of internal and external directors.

Following the study of Andres and Vallelado (2008) the fourth hypothesis was developed to find out the optimal mix of internal and external directors.

$\mathrm{H}_{4}$ : There is a nonlinear relationship between the proportion of independent directors and the bank performance.

\subsubsection{Gender diversity and performance}

In the recent years, increased importance was given to boards with gender diversity, especially in the aftermath of the financial crisis. Regulators at present are focusing on imposing gender quotas to the firm boards. The impact of gender diversity in the boardroom has been a wellresearched finance topic throughout the years(Carter, Simkins \& Simpson, 2003; Adam \& Ferreira, 2009; Pathan \& Faff, 2013; Farag \& Mallin, 2017). However, the percentage of female directors in the boards has increased steadily, but very slowly over the years. According to the European Commission report (2015), an average of $21.2 \%$ of the board members of the largest publicly listed companies in the EU are women, a notable increase from $11.9 \%$ in 2010 .

The existing literature suggests that female directors are capable of creating firm value, as they are hardworking and have better communication skills which will contribute to an enhanced problem-solving and decision-making ability of the board (Robinson \& Dechant, 1997). Adam and Ferreira (2009) found that female directors have fewer attendance problems and greater the percentage of female directors better the attendance of male directors. Further, he stated that female directors mostly sit in monitoring committees such as audit, nomination and corporate governance committees, and gender diverse boards put more effort to monitoring. Supporting the above argument, Eagly and Carli (2003) found that women tend to come better prepared for meetings and take their responsibility seriously. As per this finding that women put more effort into their task, it could be argued that their effort improve the board effectiveness.

There is mixed evidence on the impact of the gender diversity on firm performance in studies conducted in the non-financial sector. Adam and Ferreira (2009), using the data on Standard \& Poor 500 companies found that female directors have an overall negative effect on the firm performance, which was consistent with the argument that too much board monitoring can decrease shareholder value. Having a larger proportion of female directors will be beneficial if additional monitoring would enhance firm value. Further, they found that for firms with weaker shareholder rights, gender diversity has beneficial effects, while it has detrimental effects on companies with strong shareholder rights.

Using a sample of major US corporations, Carter et al. (2010) found that there is no significant relationship between gender diversity of the board and financial performance. The findings 
of the above are consistent with the contingency theory that the effect of gender diversity on firm performance is dependent on various internal and external environments. Thus, gender diversity may be desirable in some firms and not in others. Similarly, Randoy, Thomsen, \& Oxelheim, (2006), Farrell and Herschg (2005) and Francoeur, Labelle and Desgagne (2007) found that gender diversity has no impact on financial performance.

On the contrary, Carter, Simkins and Simpson (2003) and Campbell and Minguez-Vera (2008) found a positive relationship between gender diversity and performance as measured by Tobin Q for a sample of companies from USA and Spain, respectively. Similarly, Kim and Starks (2016) presented evidence that a higher percentage of female directors presented higher company valuation using the firms in the S\&P Small Cap 600 Index as the sample.

There have been relatively fewer studies conducted on the relationship between gender diversity and the performance in the banking industry and the results of those studies are inconclusive. Pathan and Faff (2013) found that gender diversity improves the bank performance prior to the introduction of Sarbanes Oxley Act(SOX)(1997-2002), and positive effect of gender diversity decreases during the post-SOX (2003-2006) and crisis periods (20072011), interpreting that more female directors beyond the desirable level prevent the possibility of the inclusion of more capable male directors. Also, the main reason for including more female directors in the post-SOX period may be due to public pressure rather than the best choice.

Joecks, Pull, and Vetter (2012) found a U-shaped relationship between gender diversity and firm performance. They found that at first gender diversity affects firm performance negatively. Gender diversity improves firm performance only after a critical mass of $30 \%$ of female directors are reached. Farag and Mallin (2017) found that relationship between gender diversity and financial performance is nonlinear and has an inverted U-shaped relationship for unitary boards. That is, appointing female directors up to $21 \%$ increases the financial performance, while beyond $21 \%$ it decreases the bank performance. The above findings are consistent with the arguments that female directors are risk averse compared to male counterparts and hence reduce bank performance. Consistent with the critical mass theory of Kanter (1977), they found that the relationship is U-shaped in management boards of the dual board structures and appointing female directors beyond a critical mass of $27 \%$ has a positive impact on firm financial performance.

There is no formal theory which explains the effect of gender diversity on firm performance. The current knowledge is mainly related to empirical findings of existing studies (Pathan \& Faff, 2013). The differences in results of the studies are due to different samples, time periods, industry coverage as well as the econometrics problems such as endogeneity. According to Wintoki et al. (2012) due to the presence of endogeneity of the governance variables, the findings of such studies will be biased if the researchers do not adequately control reverse causality and unobservable heterogeneity. 
Based on the existing literature, female representation on the boards has advantages as well as disadvantages. The existing understanding is that gender diversity will enhance a firm's value, and based on the resource dependency theory and human capital theory, Farag and Mallin (2017) argued that female directors will bring the board a degree of diversity in backgrounds, experiences and opinions, which may lead to better financial performance. Therefore, following the studies of Farag and Mallin (2017) and Pathan and Faff (2013), a positive relationship is expected between the proportion of female directors and bank performance, assuming gender diversity will enhance the monitoring and advisory role of the board of directors. Based on the above, the following hypothesis is developed regarding gender diversity.

$\mathrm{H}_{5}$ : There is a positive relationship between the proportion of female directors and the bank performance.

The study is also interested in finding whether there is a nonlinear relationship between the proportion of female directors and bank performance. That is whether there is a critical mass of female directors need to be present in the bank boards to get the benefit of gender diversity. Therefore, the final hypothesis of the study is developed as follows.

$\mathrm{H}_{6}$ : There is a non-linear relationship between the proportion of female directors and bank performance.

\section{Institutional background}

\subsection{Corporate Governance in the European Union (EU)}

The EU has grown into a union of 28 member states accounting for more than $24 \%{ }^{2}$ of the world's GDP. The EU is a region where business cooperation among member states are common, and it facilitates the single market among the member states. The EU has become one of the fastest changing corporate governance environments in the world due to the European Commission's (EC) focus on corporate governance.

In 2012, the EC published the EU Action Plan for developing corporate governance practices among EU member states. The member states have their national corporate governance codes (e.g. UK Corporate Governance Code, CG Codes and Principles in France) and divergences of practices exist among the member states (International Finance Corporation, 2015).

The board structure of EU consists of either unitary or dual Boards. Out of 28 Euro member states 8 countries have a unitary board system, 10 countries have a dual board system and the remaining 10 countries follow a hybrid approach where companies are allowed to choose

\footnotetext{
${ }^{2}$ Share of World GDP, 2014: The EU in the world 2016, a Eurostat Publication. Next planned update is in June 2018
} 
between unitary and dual boards (EC, 2013). Table 3.1 below lists the member states with their board structures.

Based on the survey conducted by Heidrick and Struggles (2014), the board sizes and the board composition, i.e. the proportion of executive and non-executive directors vary significantly between member states. Also, there has been a growing focus on increasing board diversity especially gender diversity in the corporate boards (IFC, 2015).

Table 3-1: Board Structure of EU countries followed by date of membership

\begin{tabular}{lll}
\hline \hline Unitary Boards & Dual Boards & Hybrid \\
\hline Belgium (1952) & Germany (1952) & France (1952) \\
Ireland (1973) & Netherlands (1952) & Italy (1952) \\
Spain (1986) & Austria (1995) & Portugal (1986) \\
United Kingdom (1973) & Czech-republic (2004) & Bulgaria (2007) \\
Sweden (1995) & Denmark (1973) & Hungary (2004) \\
Greece (1981) & Poland (2004) & Luxemburg (1952) \\
Malta (2004) & Finland (1995) & Slovenia (2004) \\
Cyprus (2004) & Slovakia (2004) & Lithuania (2004) \\
& Latvia (2004) & Croatia (2013) \\
& Estonia (2004) & Romania (2007) \\
\hline
\end{tabular}

Source: IFC (2015) and European Commission (2013). Countries denoted in bold letters are the sample of countries used in this study.

Regulation on board size: The Basel Committee on Banking Supervision (BCBS,2015) suggests that a board should comprise of individuals to commensurate with the size, complexity and risk profile of the bank. In line with the above national CG codes did not stipulate a strict limit on the number of board of directors but stated that the board size should be in line with the size and complexity of the firm. Furthermore, in line with the above provision, individual banks have set limits on the minimum and a maximum number of board directors, which correlate with the size and complexity of business operations. E.g. MedioBanca in Italy has set a limit of a maximum of 15 directors on the board (Medio Banca Annual Report 2016/17).

Regulation on board composition: As per the BCBS guidance (2015), a Board should comprise a sufficient number of independent directors to facilitate effective oversight (BCBS, 
2015). Regarding board composition, there are differences in national regulation. E.g. The UK CG code suggests that the best practice is that at least half of the board, excluding the chairman, should comprise of independent non-executive directors (UK Corporate Governance Code, 2016), whereas in the CG code in Italy the proportion of independent directors should be $1 / 3$ of the total number of board members (Corporate Governance Committee-Borsa Italiana, 2015).

Regulation on gender diversity: Norway was the first country to introduce a compulsory gender quota of 40\% in 2003, and following this Spain (2007), Belgium (2011), France (2011), Italy (2011), Netherlands (2013) and Germany (2016) also introduced compulsory gender quota targets. Countries such as Austria and Greece also have imposed quotas for state owned companies (European Commission, 2015). In 2012, the EU Commission proposal set a gender quota of $40 \%$ to improve the gender balance of Non-Executive Directors (NED) in listed companies by 2020. On November 20, 2013, the European parliament approved the proposal with a strong majority, confirming the broad consensus towards the initiative (EC, 2015).

Table 3-2: Country statistics on gender quota

\begin{tabular}{lrrr}
\hline \hline Country & Quota (\%) & $\begin{array}{l}\text { Date of } \\
\text { Compliance or } \\
\text { expected date of } \\
\text { compliance }\end{array}$ & $\begin{array}{l}\text { Share of } \\
\text { women on } \\
\text { boards (*) }\end{array}$ \\
\hline Belgium & $33 \%$ & 2017 & $23.4 \%$ \\
France & $40 \%$ & 2017 & $32.8 \%$ \\
Germany & $30 \%$ & 2016 & $25.4 \%$ \\
Spain & $40 \%$ & 2015 & $16.8 \%$ \\
Italy & $33 \%$ & 2015 & $25.8 \%$ \\
Netherlands & $30 \%$ & 2016 & $23.8 \%$ \\
Austria & State owned & 2018 & $17.8 \%$ \\
Greece & companies 35\% & & $10.3 \%$ \\
& $33 \%$ (State owned & & \\
\hline
\end{tabular}

* Latest update as of April 2015: European Commission Database on Women on Decision Making

\subsection{Banking sector in the EU}

The total assets of the EU banking sector stood at $€ 27.7$ trillion at the end of 2015. Based on the size of the banking sector assets, France and Germany are the largest, followed by Spain and Italy, respectively (European Central Bank, 2016).

\subsection{Corporate governance of the banks in the EU}

Corporate governance in banking institutions received much attention after the global financial crisis. Many hold the view that banking institutions should have strict corporate 
governance requirements than other non-financial firms. Governance weaknesses at banks play a significant role in increasing riskiness and transmitting the problems of the banking sector across the economy. Therefore, bank supervisors have identified the importance of sound corporate governance practices to the safe and soundness of the banking institution.

In October 2013, a single supervisory mechanism was established in the EU, and the European Central Bank (ECB) was entrusted as the supranational supervisory body to oversee banking supervision. Under the European System of Financial Supervision (ESFS), three supervisory authorities together with the national supervisors and the European Systemic Risk Board undertake a three-tier approach to supervision. The ECB or European Banking Authority has not mandated any CG requirements for banking institutions; hence banks in the member states need to follow their respective national code of CG.

In some of the EU countries, the national supervisor has mandated CG requirements for banks in addition to the national CG codes. E.g. in the UK the Prudential Regulatory Authority (PRA) has issued a supervisory statement stating the aspects of CG they devote attention to in the course of its supervision function.

Also, the BCBS has issued a consultative document on "Corporate Governance principles for banks" which will be followed by the member jurisdictions.

\section{Data and methodology}

\subsection{Sample size}

The sample consists of the annual data of the 45 largest European banks with a unitary board system as per the Banker's Top 1000 World Bank Report 2013. ${ }^{3}$ The report ranks the financial institutions across the globe based on several parameters such as strength, size, soundness, profit and performance. The annual data of the aforementioned banking institutions, which comprised of unitary boards was collected over the period from 2010-2015. Following the study of Farag and Mallin (2017), the sample was constrained to the banks in the European Union (EU) and the members of the European Economic Area (EEA) due to the similar regulatory and governance backgrounds. Also, other credit institutions including mortgage banks and building societies were excluded from the sample due to the differences in the business model.

Out of the EU countries with unitary boards, Cyprus and Malta were excluded due to the nonavailability of data. From the countries with hybrid board structures, the sample that was selected consisted of banks with unitary boards. Bulgaria, Hungary, Luxemburg, Slovenia,

\footnotetext{
${ }^{3}$ Banker's Top 1000 World Bank Report 2013 report was the latest available at the library of University of Birmingham.
} 
Lithuania, Croatia and Romania were excluded as it has less than 2 banks in the Top 1000 banks list as well as the non-availability of data. As a result, the final sample consists of Belgium, Ireland, Spain, United Kingdom, Sweden, France, Greece, Italy and Portugal from the EU countries. Switzerland was selected as a sample country as it is a member of the EEA and has access to the single market along with the other EU countries. Following the study of Farag and Mallin (2017), Norway was excluded because it introduced a compulsory gender quota for listed companies in which female directors should be at least $40 \%$. Therefore, the final sample consists of 10 countries in the European region, which include 45 of the largest European banks with unitary board structures.

The corporate governance data were mainly collected from the DataStream Asset 4 ESG database, and the rest of the governance data were hand collected from the annual reports. Financial data was obtained from DataStream, Thomson one, Fitch Connect and Bloomberg databases. The dataset is an unbalanced panel dataset with 270 bank-year observations of 45 banks over the period from 2010-2015. Table 4.1 below illustrates the distribution of banks across the 10 countries.

Table 4-1: Country-wise sample

\begin{tabular}{lc}
\hline \hline Country & No. of banks in the sample \\
\hline Belgium & 2 \\
Ireland & 3 \\
Spain & 6 \\
United Kingdom & 5 \\
Sweden & 4 \\
France & 3 \\
Greece & 4 \\
Italy & 9 \\
Portugal & 3 \\
Switzerland & 6 \\
\hline
\end{tabular}

Source: Compiled by the Author

\subsection{Description of variables}

\section{Measures of bank performance}

Following the study of Pathan and Faff (2013), four alternative proxies for bank performance (PEFOR) were used to investigate the relationship between board structure and bank performance. Return on average assets (ROAA), net interest margin (NIM), Tobin Q ratio (Q) and stock return (SR) were used as the proxies for bank performance. ROAA was computed as net income as a percentage average book value of total assets of the two most recent years. NIM is a commonly used performance measure for the bank's financial performance. It is calculated as net interest income (gross interest minus total interest 
expense) as a percentage of average earning assets. Earning assets include loans that generate interest income. Many studies conducted to test the effectiveness of corporate governance mechanisms used Tobin Q as one of the dependent variables. (Pathan \& Faff, 2013; Andres and Vallelado, 2008; Adam \& Mehran, 2012; Caprio et al., 2007). Tobin Q is computed as the sum of market value of equity plus the book value of liabilities divided by book value of total assets. A Tobin Q of higher than one reflects the firm's comparative advantage, while lower than one reflects poor utilisation of resources. (Campbell \& Mínguez-Vera, 2008; Rose, 2007). Since all the banks in the sample are listed, SR was used as a proxy for banks performance as well. SR is the mean of the daily stock returns in a year. The daily stock return is calculated as the ratio of logarithmic stock prices. The study includes various proxies of performance to confirm that results are robust to changes in the dependent variable. Even though Tobin $Q$ is the most common measure of performance in corporate governance studies, Andres and Vallelado (2008) argued that the high leverage of banks biases the Q ratio to be one. Due to this, alternative performance measures were selected, which comprised of accounting based measures of performance (ROAA \& NIM) and market-based measures of performance (SR).

\section{Measures of Board Structure/explanatory variables}

Studies which test the impact of corporate governance on firm performance commonly used three variables to measure the board structure. i.e., the natural logarithm of board size (LnBS), board independence (IND) and gender diversity (FEMALE). LnBS is the natural logarithm of a total number of directors in the board. Natural logarithm was used to account for large variations of the data in the sample (Minimum 3, maximum 30). IND is the percentage of independent ${ }^{4}$ Directors in the board and FEMALE is the percentage of female directors on the board. As per the detailed explanation provided in the literature review and research hypothesis, this study expects a positive relationship between board size, the proportion of independent directors, the proportion of female directors and the bank performance.

4 Data Stream Asset 4 ESG database define Independent Director as a Director who is" not employed by the company; not representing or employed by a majority shareholder; not served on the board for more than ten years; not a reference shareholder with more than $5 \%$ of holdings; no cross-board membership; no recent, immediate family ties to the corporation; not accepting any compensation other than compensation for board service. 
Table 4-2: Description of variables

\begin{tabular}{|c|c|c|c|c|}
\hline Notation & $\begin{array}{l}\text { Variable } \\
\text { Name }\end{array}$ & Description of variables & Source & $\begin{array}{l}\text { Expected } \\
\text { Sign }\end{array}$ \\
\hline ROAA & $\begin{array}{l}\text { Return on } \\
\text { Average } \\
\text { Assets }\end{array}$ & $\begin{array}{l}\text { Net income divided by the } \\
\text { average book value of total } \\
\text { assets. }\end{array}$ & $\begin{array}{l}\text { Fitch } \\
\text { Connect }\end{array}$ & \\
\hline NIM & $\begin{array}{l}\text { Net Interest } \\
\text { Margin }\end{array}$ & $\begin{array}{l}\text { Net interest income as a } \\
\text { percentage of average } \\
\text { earning assets. }\end{array}$ & $\begin{array}{l}\text { Fitch } \\
\text { Connect }\end{array}$ & \\
\hline Q & Tobin Q Ratio & $\begin{array}{l}\text { The sum of market value of } \\
\text { equity plus the book value } \\
\text { of liabilities divided by the } \\
\text { book value of total assets. }\end{array}$ & $\begin{array}{l}\text { Calculated } \\
\text { using data of } \\
\text { Fitch } \\
\text { Connect }\end{array}$ & \\
\hline SR & Stock Return & $\begin{array}{l}\text { The mean of the daily stock } \\
\text { returns in a year. The daily } \\
\text { stock return is computed as } \\
\text { the ratio of logarithmic } \\
\text { stock prices }\end{array}$ & $\begin{array}{l}\text { Bloomberg } \\
\text { daily stock } \\
\text { prices }\end{array}$ & \\
\hline \multicolumn{5}{|c|}{ Explanatory Variables } \\
\hline LnBS & $\begin{array}{l}\text { Natural } \\
\text { logarithm of } \\
\text { Board Size }\end{array}$ & $\begin{array}{l}\text { Natural logarithm of the } \\
\text { total number of directors at } \\
\text { the end of fiscal year }\end{array}$ & $\begin{array}{l}\text { DataStream } \\
\text { Board Size }\end{array}$ & + \\
\hline IND & $\begin{array}{l}\text { Board } \\
\text { Independence }\end{array}$ & $\begin{array}{l}\text { Independent Directors as a } \\
\% \text { of total directors }\end{array}$ & $\begin{array}{l}\text { DataStream } \\
\text { Value: Board } \\
\text { Structure/In } \\
\text { dependent } \\
\text { board } \\
\text { members }\end{array}$ & + \\
\hline FEMALE & $\begin{array}{l}\text { Gender } \\
\text { Diversity }\end{array}$ & $\begin{array}{l}\text { female directors as a } \% \text { of } \\
\text { total directors }\end{array}$ & $\begin{array}{l}\text { DataStream } \\
\text { Value: Board } \\
\text { Structure/Bo } \\
\text { ard Gender } \\
\text { Diversity }\end{array}$ & + \\
\hline
\end{tabular}




\begin{tabular}{|c|c|c|c|c|}
\hline Notation & $\begin{array}{l}\text { Variable } \\
\text { Name }\end{array}$ & Description of variables & Source & $\begin{array}{l}\text { Expected } \\
\text { Sign }\end{array}$ \\
\hline \multicolumn{5}{|c|}{ Control Variables } \\
\hline TA & Bank Size & $\begin{array}{l}\text { Banks total assets in billions } \\
\text { as a proxy for bank size }\end{array}$ & $\begin{array}{l}\text { Fitch } \\
\text { Connect }\end{array}$ & + \\
\hline CAPITAL & Bank Capital & $\begin{array}{l}\text { The regulatory measure of } \\
\text { bank's capital: Tier } 1 \text { capital } \\
\text { adequacy ratio }\end{array}$ & $\begin{array}{l}\text { Fitch } \\
\text { connect }\end{array}$ & + \\
\hline MERGER & $\begin{array}{l}\text { Merger and } \\
\text { Acquisition }\end{array}$ & $\begin{array}{l}\text { A dummy variable of } 1 \text { if } \\
\text { M\&A during the sample } \\
\text { period and zero otherwise. }\end{array}$ & Bloomberg & + \\
\hline LnGDP & $\begin{array}{l}\text { Gross } \\
\text { Domestic } \\
\text { Product }\end{array}$ & $\begin{array}{l}\text { Natural logarithm of GDP } \\
\text { in Euros }\end{array}$ & Bloomberg & + \\
\hline
\end{tabular}

Source: Compiled by the Author

\section{Control Variables}

Following the previous studies of Pathan and Faff (2013), Farag and Mallin (2017), Andres and Vallelado (2008) and Adam and Mehran (2012), 4 other control variables were used to capture much of the error term in the regression model. The control variables were selected to account for differences in the banks' business structure and risk profile as well as to reflect on the differences between the countries. I.e., it is aimed at controlling bank and country heterogeneity.

Bank's total assets measured in billion euros as a proxy for bank size (TA) as the performance of large banks may differ from smaller banks, and larger banks tend to have larger boards. Tier 1 capital adequacy ratio (CAPITAL) as a measure of the risk appetite of the Board and the management of risk. Higher CAR represents higher loss absorbent capacity and risk averseness. MERGER is a dummy variable indicating merger and acquisitions in the sample period, because following an M\&A the bank board size tends to increase to accommodate directors from the target company. The natural logarithm of GDP in Euros (Ln GDP) to reflect the macroeconomic condition of each country was also included in the regression model. Firm and year dummies were used to capture firm and time heterogeneity, respectively.

\subsection{Methodology}

Panel data analysis is the most efficient tool to use when the sample consists of a mixture of cross-sectional and time series data. The panel data structure can take into account the heterogeneity, i.e., the specific features among each bank being studied (e.g. management style 
and quality, business strategy). Pooled Ordinary Least Squares(OLS) estimation is biased and inconsistent when there is an unobserved effect and it correlates with the independent variable (Andres \& Vallelado, 2008).

The panel least squares model can be specified as either using fixed effects or random effects. The fixed effect model captures the unobserved heterogeneity arising from firm specific time invariant variables. In the presence of the unobserved bank fixed-effect, panel 'Fixed-Effect' (FE) estimation is commonly suggested (Wooldridge,2002). A number of studies conducted on the topic used the fixed effect model opposed to the random effect model due to the possibility of capturing unobserved heterogeneity (Adam \& Mehran, 2012; Adam \& Ferreira, 2009; Pathan \& Faff, 2013; Farag \& Mallin, 2017).

A central assumption in random effects estimation is the assumption that the random effects are uncorrelated with explanatory variables. The study employed the Hausman Specification Test to select the appropriate model. In this test the Null hypothesis $\left(\mathrm{H}_{0}\right)$ is that there is a zero correlation between the random effects and the explanatory variables (Lindquist, 2004). If the null hypothesis is rejected there is no random effects, and fixed effects can be applied. Results of the Hausman Specification Test favours the use of fixed effects since the Prob $>$ chi 2 is less than 0.05 for all the four dependent variables.

When deciding on the appropriate estimation method, it is important to consider alternative methods used in prior studies. Many academic literatures on corporate governance argue about the problem of endogeneity ${ }^{5}$ in governance variables. Two main sources of endogeneity exist in the governance studies. Namely, Unobserved Heterogeneity ${ }^{6}$ and Reverse Causality ${ }^{7}$. To address the above concern, some studies used the fixed effects panel which is estimated to control firm heterogeneity and limit the omitted variable bias (Adam and Mehran, 2012; Adam and Ferreira, 2009).

Adam and Ferreira (2009) used the firm fixed effect to capture the effect of any other time invariant firm characteristics that might be driving the result other than the governance variables used in the regression model. For example, variables such as corporate culture (Adam \& Ferreira, 2009) and the ability and effort of directors (Pathan \& Faff, 2013). By the incorporation of fixed effects, it is assumed that individual specific effect ( $\mu$ i) captures all of the variables that affect the firm performance cross-sectionally that do not vary over the time (Brooks, 2008). Adam and Mehran (2012) included year dummies and firm fixed effects and used a rich set of governance variables (to limit the omitted variable bias and to avoid spurious

\footnotetext{
${ }^{5}$ Endogeneity, i.e. the firm performance is correlated with the error term than the governance variables. ${ }^{6}$ Unobserved Heterogeneity Unobserved differences across the units being studied like ability and effort, performance of the firm is merely a result of underlying unobservable factor)

${ }^{7}$ Reverse Causality: The relation between two events that are happening at the same time. e.g. board structure affects bank performance and in the same time bank performance drives governance structure) See, for example, Pathan and Faff (2013); Farag and Mallin (2017); Andres and V allelado (2008); Adam and Ferreira (2009).
} 
correlation) to address the endogeneity concerns. But the researchers who used the fixed effect model accepted that their results would be biased by reverse causality. Researchers such as Pathan and Faff (2013), Farag and Mallin (2017) Wintoki et al (2012), Andres and Vallelado (2008) used the two step system GMM adopted by Arellano and Bover (1995) and Blundell and Bond (1998) as the primary estimation to control all sources of endogeneity. But the scope of this study is the association of governance variables on bank performance and hence ignored the problem of reverse causality. This will be further discussed in the limitation section of the study.

Following the study of Adam and Mehran (2012) and Adam and Ferreira (2009), the main estimation method used is the firm fixed effects with year dummies. It is important to incorporate the "year dummies" in panel regressions to control the effect of aggregate time series trends, which do not describe causal relationships.

The following regression equation will be used to test the six-main hypotheses $\left(\mathrm{H}_{1}, \mathrm{H}_{2}, \mathrm{H}_{3}\right.$, $\left.\mathrm{H}_{4}, \mathrm{H}_{5}, \mathrm{H}_{6}\right)$.

$$
\begin{aligned}
(\text { PERFOR })_{i, t}= & \propto_{0}+\beta_{1}(\text { LnBS })_{i, t}+\beta_{2}(\text { IND })_{i, t}+\beta_{3}(F E M A L E)_{i, t}+\tau_{1}(T A)_{i, t} \\
& +\tau_{2}(\text { CAPITAL })_{i, t}+\tau_{3}(\text { MERGER })_{i, t}+\tau_{4} \ln (G D P)_{i, t}+\mu_{i, t}+\varepsilon_{i, t}
\end{aligned}
$$

Where subscript $i$ denotes individual banks and $t$ denotes the time. $(P E R F O R)_{i, t}$ is the dependent variable (i.e. ROAA, NIM, Q, SR) The coefficient $\alpha, \beta, \tau$ are the parameters to be estimated. $\mu$ is the remaining unobserved fixed effect for bank i. and $\varepsilon_{i j}$ denotes the remaining disturbance term.

In addition to the results of the fixed effect model, results of the Pooled OLS model will be presented as a robustness check in the next chapter. The data were analysed using the Stata SE 14 software package.

\section{Empirical results}

\subsection{Summary statistics}

Table 5.1 below presents the descriptive statistics of the main independent and dependent variables used in the study. The average board size in the sample is 15 directors, where the maximum is 30 and minimum is 3 directors. The large discrepancy may be attributed to the non-availability of regulations related to the number of board of directors in the sample of 10 countries used in this study. The numbers are similar to the study conducted by Farag and Mallin (2017) using a dataset for the period of 2004-2012. The average proportion of independent directors is $53 \%$ with a standard deviation of $25 \%$ and ranges from $0 \%$ to $98 \%$. It was noted in the sample of countries that Belgium has the highest proportion of independent directors. The proportion of female directors ranges from $0 \%$ to $53 \%$, with an average of $18 \%$. This number is higher than the $10 \%$ average reported by Farag and Mallin 
(2017) in their sample. The number of female representation improved over the last few years due to various measures taken by EU member states to promote gender diversity and the imposition of mandatory gender quotas. Furthermore, the average capital ratio was $12.8 \%$ with a minimum of $6.1 \%$ and a maximum of $29.3 \%$. There has been a merger at least one time for around $20 \%$ of the sample of banks in the study during the sample period. Larger discrepancies were noted in the proxies for financial performance whereas average ROAA is $-5.6 \%$ and ranges from $4.16 \%$ to $-145 \%$. The main reason behind this is the poor financial performance of the banks in countries such as Greece, Italy and Ireland as they are still recovering from the aftermath of the GFC and the Eurozone crisis. Country wise summary statistics will be discussed in the next paragraph. The description of other variables was omitted for brevity.

Table5-1: Descriptive statistics

\begin{tabular}{lccccc}
\hline \hline & $(1)$ & $(2)$ & $(3)$ & $(4)$ & $(5)$ \\
VARIABLES & $\mathrm{N}$ & mean & $\mathrm{sd}$ & $\min$ & $\max$ \\
\hline & & & & & \\
BS & 270 & 15.21 & 5.265 & 3 & 30 \\
IND & 270 & 0.534 & 0.258 & 0 & 0.980 \\
Female & 270 & 0.183 & 0.117 & 0 & 0.538 \\
ROAA & 270 & -0.0569 & 0.889 & -14.60 & 0.0416 \\
NIM & 270 & 0.0136 & 0.0275 & -0.423 & 0.0390 \\
Q & 268 & 1.042 & 0.170 & 0.906 & 1.878 \\
SR & 258 & -0.0008 & 0.0031 & -0.0228 & 0.0063 \\
TA & 270 & 471.7 & 581.1 & 0.159 & 2,213 \\
CAPITAL & 270 & 0.128 & 0.0455 & -0.0610 & 0.293 \\
MERGER & 270 & 0.204 & 0.403 & 0 & 1 \\
LnGDP & 270 & 27.13 & 1.035 & 25.77 & 28.58 \\
\hline PAS
\end{tabular}

Please refer table 4.2 for the definition of each variable.

As represented by figure 5.1 below, Portugal (20) has the largest number of Board of Directors followed by Italy (19.7), Belgium (17.4) and France (17.2). Figure 5.2 below represents the average proportion of independent directors on the board in the sample of 10 countries from 2010 - 2015.The highest proportion of independent directors was evident in the sample banks of Belgium (94\%).Countries such as Portugal, Italy and Greece only have 1/3 of directors as independent directors, and in most countries, at least half of the directors are comprised of independent directors. The differences are due to the differences in national codes of corporate governance. E.g. in Italy the CG code mandated at least $1 / 3$ of independent directors on the board and as per the UK code of corporate governance, it should be at least half. France $(36 \%)$ and Sweden $(35 \%)$ have the highest proportion of female directors in the board, while Portugal (5\%) and Greece $(11 \%)$ have the lowest representation of female directors (Figure 5.3). The higher proportion of female representation in France is attributed to the gender quota of $40 \%$ which is mandatory by the year 2017 . Despite having gender 
quotas Spain, Italy and Greece have low female representation in the boards. Figure 5.4 below presents the average proportion of female directors in the sample of 10 countries year by year and shows that the average proportion increases from $13.8 \%$ in 2010 to $24.9 \%$ in 2015 . Figure 5.5 below summarises the cross-country analysis of average values for independent and dependent variables.

Figure 5-1: Average Board Size by country 2010-2015

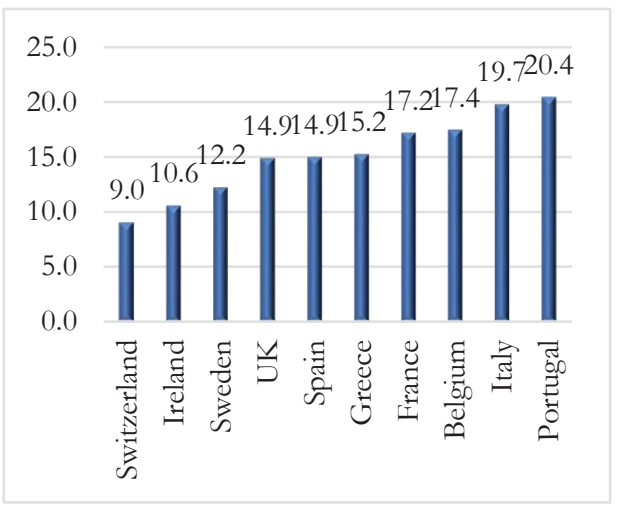

Figure 5-3: Average proportion of female directors by country $2010-2015$

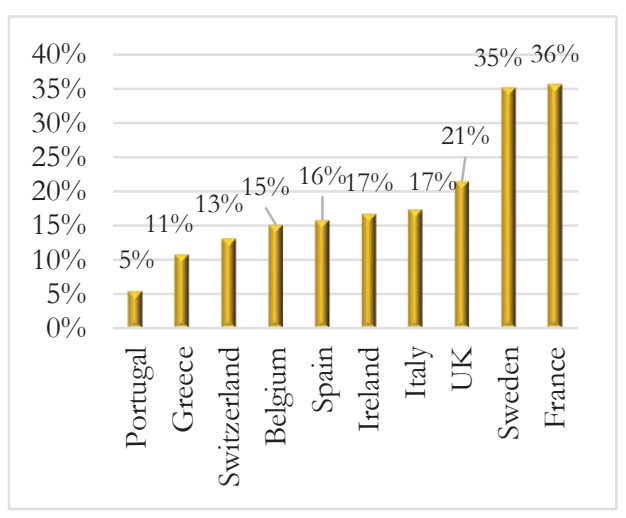

Figure 5-2: Proportion of average independent directors by country $2010-2015$

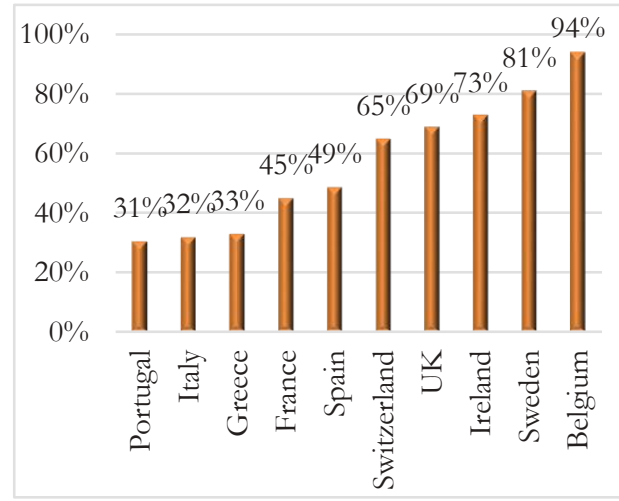

Figure 5-4: Average proportion of female directors sitting on unitary boards 2010-2015

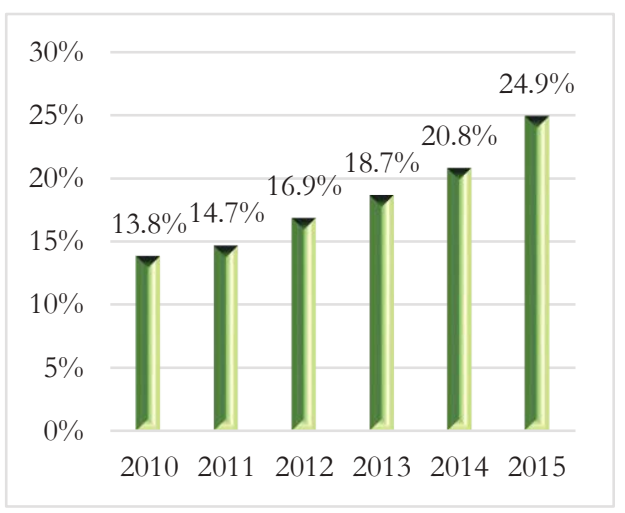









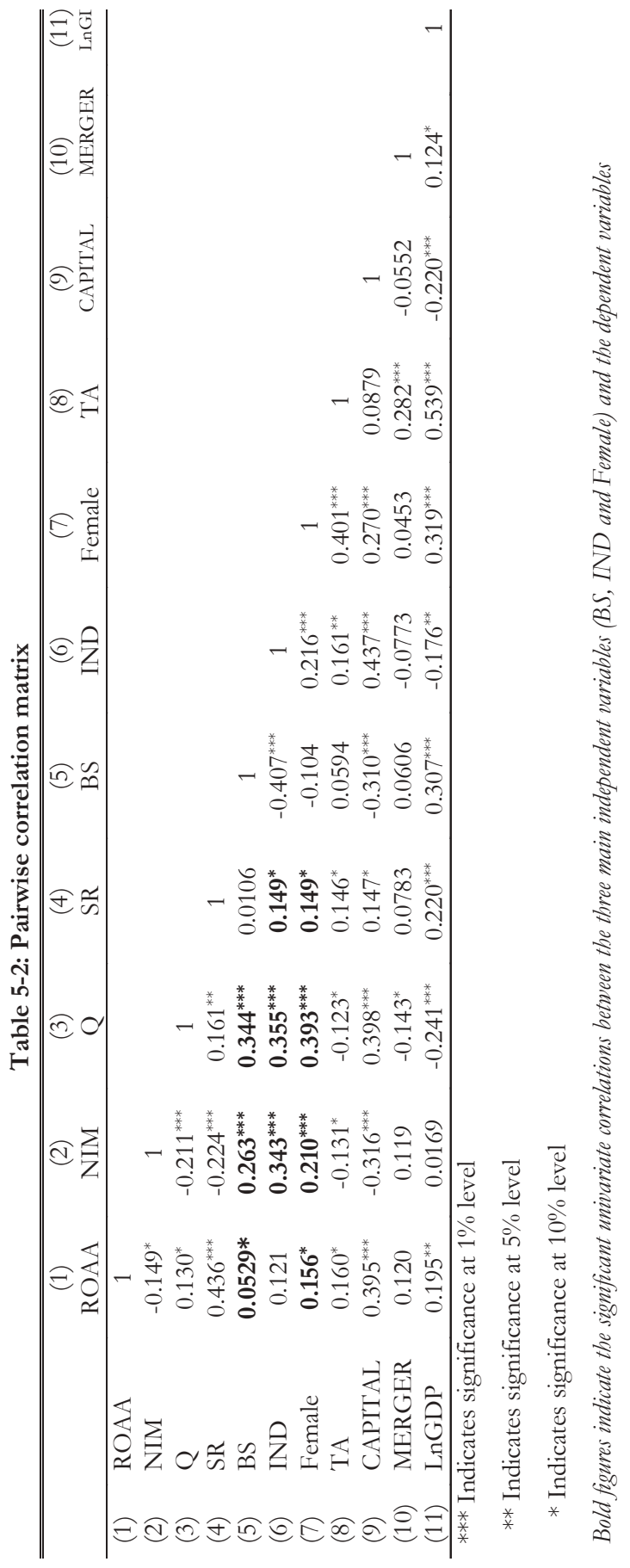




\subsection{Correlation matrix}

Table 5.2 above presents the correlation matrix for the main variables used in this study. Multicollinearity occurs when there is a strong correlation between two or more independent variables in the model. Multicollinearity reduces the statistical power of the analysis and can cause the coefficients to switch signs and makes it more difficult to specify the correct model. In general, correlation above 0.6 is considered as a high correlation, which considered as problematic to include in the model. As per the above matrix, there is no evidence of high collinearity and therefore, the model specification will not be problematic. Highest correlation is $53 \%$, which is between total assets and the LnGDP.

The univariate correlations between board size (BS) and performance measures are significant and positively correlated except for the stock return. Percentage of independent directors are positive and significant for performance measures except for ROAA. Also, the univariate correlation for the proportion of female directors is significant and positive for all the four alternative proxies of performance.

\subsection{Results of the pooled ordinary least squares (OLS)}

The initial multivariate regression results using pooled OLS is presented in Table 5.3 below for all the four dependent variables. Board size is positive and statistically significant at a $1 \%$ level, supporting the $\mathrm{H}_{1}$ that board size is positively related to bank performance. For the proportion of independent directors, the estimated coefficient is positive, and it is statistically significant when the performance is proxied by ROAA, Q and SR and consistent with the expected sign of $\mathrm{H}_{3}$. The coefficient of the female directors is positive and statistically significant at a $1 \%$ level when performance is proxied by Tobin $\mathrm{Q}$. This supports the expected sign of $\mathrm{H}_{5}$. 
Table 5-3: The effect of board structure on bank performance-Pooled OLS

\begin{tabular}{|c|c|c|c|c|}
\hline \multirow[b]{3}{*}{ VARIABLES } & \multicolumn{3}{|c|}{ Pooled OLS } & \multirow[b]{2}{*}{ (4) } \\
\hline & (1) & (2) & (3) & \\
\hline & ROAA & NIM & Q & SR \\
\hline \multirow[t]{2}{*}{ LnBS } & $0.806 * * *$ & $0.029 * * *$ & -0.039 & -0.000 \\
\hline & $(0.153)$ & $(0.005)$ & $(0.028)$ & $(0.001)$ \\
\hline \multirow[t]{2}{*}{ IND } & $0.438 *$ & 0.009 & $0.122 * * *$ & $0.002 * * *$ \\
\hline & $(0.227)$ & $(0.007)$ & $(0.038)$ & $(0.001)$ \\
\hline \multirow[t]{2}{*}{ Female } & 0.541 & 0.010 & $0.753 * * *$ & 0.000 \\
\hline & $(0.520)$ & $(0.016)$ & $(0.086)$ & $(0.002)$ \\
\hline \multirow[t]{2}{*}{ TA } & -0.000 & -0.000 & $-0.000 * * *$ & -0.000 \\
\hline & $(0.000)$ & $(0.000)$ & $(0.000)$ & $(0.000)$ \\
\hline \multirow[t]{2}{*}{ CAPITAL } & $5.933 * * *$ & $0.145^{* * *}$ & $0.602 * *$ & 0.005 \\
\hline & (1.383) & $(0.043)$ & $(0.244)$ & $(0.005)$ \\
\hline \multirow[t]{2}{*}{ MERGER } & 0.044 & 0.003 & -0.023 & 0.000 \\
\hline & $(0.133)$ & (0.004) & $(0.022)$ & $(0.000)$ \\
\hline \multirow[t]{2}{*}{ LnGDP } & 0.056 & 0.001 & $-0.019 *$ & $0.001 * * *$ \\
\hline & $(0.067)$ & $(0.002)$ & $(0.011)$ & $(0.000)$ \\
\hline \multirow[t]{2}{*}{ Constant } & $-4.573^{* *}$ & $-0.112^{* *}$ & $1.470 * * *$ & $-0.026 * * *$ \\
\hline & $(1.773)$ & $(0.055)$ & $(0.299)$ & $(0.006)$ \\
\hline Observations & 270 & 270 & 268 & 258 \\
\hline R-squared & 0.193 & 0.183 & 0.400 & 0.258 \\
\hline Firm fixed-effects & No & No & No & No \\
\hline Year dummies & Yes & Yes & Yes & Yes \\
\hline F-test(p value) & 0.000 & 0.000 & 0.000 & 0.000 \\
\hline
\end{tabular}

Standard errors in parentheses

$* * * \mathrm{p}<0.01, * * \mathrm{p}<0.05, * \mathrm{p}<0.1$

Table A2, Table A3 and Table A4 of the annexure describe the results of the pooled OLS regression estimated to test the $\mathrm{H}_{2}, \mathrm{H}_{4}$ and $\mathrm{H}_{6}$ to check the nonlinear relationships between board structure variables and bank performance. When the performance is proxied by ROAA and NIM, the results are consistent with hypothesis $2\left(\mathrm{H}_{2}\right)$ that board size has a nonlinear relationship (Table A2). The negative and significant coefficient of BS squared shows that after a certain point adding more directors will decrease bank performance. Based on the coefficient of the regressions, once the number of directors reaches 19, the bank performance starts to decrease. Similarly, when performance is proxied by ROAA and NIM the results are consistent with the hypothesis $4\left(\mathrm{H}_{4}\right)$ that the proportion of independent directors has a nonlinear relationship (Table A3). When the proportion of independent directors are above $58 \%-60 \%$ for NIM and ROAA, respectively the bank performance will decrease. The negative coefficient of the female squared represents when the proportion of female directors are above $27 \%$ and $29 \%$ for NIM and ROAA, respectively and the performance started to decrease 
(Table A4). Since pooled OLS is not the main estimation method, the results will not be discussed in detail. The detailed discussion is made when the results of the fixed effect estimation are presented.

As a post-regression, the diagnostic test to check the multicollinearity within the regressors after each regression, the Variance Inflation Factor (VIF) was obtained. The VIF of less than 10 is considered as the predetermined tolerance level for each independent variable. For all the pooled OLS regression models, the VIF values were less than 10 and hence it is believed that there is no evidence of multicollinearity. But it should be noted that this study did not attempt to compute VIF with the panel fixed effect estimates, as it is believed that the VIF is not a strong indicator because it ignores the correlations between the explanatory variable and dependent variable, and fixed effect models generate extremely large VIF scores (Jacobs, 2005). The next section describes the results of the main estimation method used in this study, i.e., firm fixed effects with the year dummies.

\subsection{Results of the fixed effects model}

\section{Board size and bank performance}

Table 5.4 below presents the results of the fixed effect estimation when performance is proxied by four different variables. As per the results of column I and II, board size has a positive and statistically significant relationship at a $1 \%$ level when the performance is proxied by ROAA and NIM. This result is consistent with the finding of the pooled OLS above. The results of the column III and IV show that there is a positive but insignificant relationship when performance is proxied by Tobin Q and stock return. The findings are consistent with the studies conducted by Adam and Mehran (2012) and O'Sullivan, Mamun and Hassan (2016) using a sample of US BHC's, where they found that the board size is positively related to performance.

The findings of this study are consistent with the argument made by Coles et al. (2008), that due to the complexity of the banks, the benefits of large boards will outweigh the costs of maintaining large boards. In a similar study, Graham, Hazarika and Narasimhan (2011) also found out that complex firms demonstrate a positive relation between board size and firm value, as complex firms benefit more from board advice. Based on the study of Adam and Mehran (2012), the main reason for the positive relationship is the value addition created by additional directors with subsidiary directorships, which facilitate the coordinating role within the larger banking group. 
Table 5-4: Results of the fixed effect estimation

\begin{tabular}{|c|c|c|c|c|}
\hline \multirow[b]{3}{*}{ VARIABLES } & \multicolumn{4}{|c|}{ Fixed Effect Estimation } \\
\hline & ROAA & NIM & Q & SR \\
\hline & $\mathrm{I}$ & II & III & IV \\
\hline LnBS & $\begin{array}{c}1.746 * * * \\
(0.259)\end{array}$ & $\begin{array}{c}\mathbf{0 . 0 5 3} * * * * \\
(0.008)\end{array}$ & $\begin{array}{c}0.022 \\
(0.029)\end{array}$ & $\begin{array}{c}0.001 \\
(0.001)\end{array}$ \\
\hline BS & & & & \\
\hline IND & $\begin{array}{c}\mathbf{0 . 9 9 7} * * \\
(0.455)\end{array}$ & $\begin{array}{c}\mathbf{0 . 0 3 0} * * \\
(0.014)\end{array}$ & $\begin{array}{c}0.002 \\
(0.036)\end{array}$ & $\begin{array}{c}0.002 \\
(0.002)\end{array}$ \\
\hline Female & $\begin{array}{c}0.421 \\
(0.905)\end{array}$ & $\begin{array}{c}0.012 \\
(0.027)\end{array}$ & $\begin{array}{c}-\mathbf{0 . 1 3 3 *} \\
(0.070)\end{array}$ & $\begin{array}{c}-\mathbf{0 . 0 0 5 *} \\
(0.003)\end{array}$ \\
\hline TA & $\begin{array}{c}0.000 \\
(0.001)\end{array}$ & $\begin{array}{c}0.000 \\
(0.000)\end{array}$ & $\begin{array}{c}0.000 \\
(0.000)\end{array}$ & $\begin{array}{c}0.000 \\
(0.000)\end{array}$ \\
\hline CAPITAL & $\begin{array}{c}5.182^{* * *} \\
(1.867)\end{array}$ & $\begin{array}{c}0.146 * * * \\
(0.056)\end{array}$ & $\begin{array}{c}0.333^{* *} \\
(0.151)\end{array}$ & $\begin{array}{l}-0.007 \\
(0.006)\end{array}$ \\
\hline MERGER & $\begin{array}{c}0.022 \\
(0.154)\end{array}$ & $\begin{array}{c}0.002 \\
(0.005)\end{array}$ & $\begin{array}{c}0.008 \\
(0.012)\end{array}$ & $\begin{array}{c}0.000 \\
(0.001)\end{array}$ \\
\hline LnGDP & $\begin{array}{l}-0.246 \\
(0.913)\end{array}$ & $\begin{array}{c}0.002 \\
(0.027)\end{array}$ & $\begin{array}{c}0.291 * * * \\
(0.070)\end{array}$ & $\begin{array}{c}0.007 * * \\
(0.003)\end{array}$ \\
\hline Constant & $\begin{array}{c}0.638 \\
(24.752)\end{array}$ & $\begin{array}{l}-0.223 \\
(0.742)\end{array}$ & $\begin{array}{c}-6.955^{* * *} \\
(1.912)\end{array}$ & $\begin{array}{c}-0.191 * * \\
(0.079)\end{array}$ \\
\hline Observations & 270 & 270 & 268 & 258 \\
\hline R-squared & 0.287 & 0.288 & 0.185 & 0.286 \\
\hline $\begin{array}{l}\text { Number of } \\
\text { banks }\end{array}$ & 45 & 45 & 45 & 45 \\
\hline $\begin{array}{l}\text { Firm fixed- } \\
\text { effects }\end{array}$ & Yes & Yes & Yes & Yes \\
\hline Year dummies & Yes & Yes & Yes & Yes \\
\hline F-Test( $(\mathrm{P}$ value $)$ & 0.000 & 0.000 & 0.000 & 0.000 \\
\hline
\end{tabular}

Even though boards with a larger number of directors are capable of better monitoring of the management, many studies point out the problems of oversized boards. (Yermack, 1996; Eisenberg et al., 1997) The researcher was also interested in testing the nonlinear relationship between board size and bank performance as excessively larger boards create coordination, control and decision-making problems. The results represented in table 5.5 below confirmed Hypothesis $2\left(\mathrm{H}_{2}\right)$ that there is an inverted $\mathrm{U}$ shape relationship between board size and bank performance when performance is proxied by ROAA and NIM. The negative coefficient in the board size squared (BS sq) proves that after a certain point adding a new director decrease 
the bank performance. This finding is consistent with the study of Andres and Vallelado (2008), where the number was around 19 for a sample of 69 commercial banks from 6 OECD countries. For this sample, the number is around 27 and 28 when bank performance is proxied by ROAA and NIM, respectively. The relatively large number can be justified based on the scope of operation hypothesis presented by Boone et al. (2007). As per the above hypothesis, the board size is positively related to firm age and firm size, a finding that is complimented by the fact that the sample consists of 45 large banks in the European region wherein the majority of the banks has a history of more than 50 years.

Table 5-5: Non-linear relationship between board size and bank performance

\begin{tabular}{|c|c|c|c|c|}
\hline \multicolumn{5}{|c|}{ Nonlinear relationship between board size and bank performance } \\
\hline & $(1)$ & $(2)$ & (3) & (4) \\
\hline VARIABLES & ROAA & NIM & $\mathrm{Q}$ & SR \\
\hline \multirow[t]{2}{*}{ BS } & $0.275 * * *$ & $0.008 * * *$ & 0.002 & 0.000 \\
\hline & $(0.090)$ & $(0.003)$ & $(0.007)$ & $(0.000)$ \\
\hline \multirow[t]{2}{*}{ BS sq } & $-0.005^{*}$ & $-0.00014 *$ & -0.000 & -0.000 \\
\hline & $(0.003)$ & $(0.000)$ & $(0.000)$ & $(0.000)$ \\
\hline \multirow[t]{2}{*}{ IND } & $1.112^{* *}$ & $0.034 * *$ & -0.002 & 0.002 \\
\hline & $(0.468)$ & $(0.014)$ & $(0.036)$ & $(0.002)$ \\
\hline \multirow[t]{2}{*}{ Female } & 0.471 & 0.014 & $-0.131 *$ & $-0.006^{*}$ \\
\hline & $(0.937)$ & $(0.028)$ & $(0.071)$ & $(0.003)$ \\
\hline \multirow[t]{2}{*}{ TA } & 0.000 & 0.000 & 0.000 & -0.000 \\
\hline & $(0.001)$ & $(0.000)$ & $(0.000)$ & $(0.000)$ \\
\hline \multirow{2}{*}{ CAPITAL } & $5.782 * * *$ & $0.164^{* * *}$ & $0.331 * *$ & -0.007 \\
\hline & (1.901) & $(0.057)$ & $(0.152)$ & $(0.006)$ \\
\hline \multirow[t]{2}{*}{ MERGER } & 0.030 & 0.002 & 0.008 & 0.000 \\
\hline & (0.158) & $(0.005)$ & $(0.012)$ & $(0.001)$ \\
\hline \multirow[t]{2}{*}{ LnGDP } & -0.234 & 0.002 & $0.291 * * *$ & $0.007 * *$ \\
\hline & $(0.937)$ & $(0.028)$ & $(0.071)$ & $(0.003)$ \\
\hline \multirow[t]{2}{*}{ Constant } & 1.883 & -0.179 & $-6.915^{* * *}$ & $-0.193^{* *}$ \\
\hline & $(25.440)$ & $(0.763)$ & $(1.925)$ & $(0.080)$ \\
\hline Observations & 270 & 270 & 268 & 258 \\
\hline R-squared & 0.256 & 0.257 & 0.184 & 0.289 \\
\hline Number of banks & 45 & 45 & 45 & 45 \\
\hline Firm fixed-effects & Yes & Yes & Yes & Yes \\
\hline Year dummies & Yes & Yes & Yes & Yes \\
\hline F test(P-value $)$ & 0.000 & 0.000 & 0.000 & 0.000 \\
\hline
\end{tabular}

Standard errors in parentheses

$$
\text { *** } \mathrm{p}<0.01, * * \mathrm{p}<0.05, * \mathrm{p}<0.1
$$




\section{Board independence and bank performance}

As presented in Table 5.4 above, for the board independence, estimated coefficient is positive and significant when performance is proxied by ROAA and NIM. The findings are in line with the $\mathrm{H}_{3}$ which expected a positive relationship between independent directors and bank performance. Also, findings of the study are similar to the findings of Mishra and Nielsen (2000), Anderson, et al. (2004) and Ashbauh-Skaife et al. (2006) who found that an increase in independent directors improves the earnings quality, lowers the cost of debt financing and improves the credit rating. Coles et al. (2008), using a sample of non-financial firms, found that the proportion of independent directors are positively related measures of firm complexity. Similar to the board size, higher proportions of independent directors in complex organisations have a positive effect on the performance through better monitoring and advice provided by independent directors when operating in complex business environments. Also, the result supports the argument that independent directors improve the monitoring of management, and reduce the conflict of interests between management and stakeholders, as they serve as the communication link between the firm and the external environment.

From the existing academic literature, it is clear that the independent directors are considered as better monitors of the management. But it does not mean that the board should be comprised of entirely independent directors. Therefore, it is important to achieve the appropriate mix between internal directors who are better with firm specific knowledge for the advisory roles and external directors who are better at monitoring. To identify the optimum proportion, the quadratic term of the proportion of independent directors was included in the model. As represented in table 5.6 below, there is a positive and significant relationship between the proportion of independent directors and bank performance. Moreover, there is a negative and significant relationship between the quadratic term of the proportion of independent directors. This proves that the relationship between the proportion of independent directors and bank performance is nonlinear and has an inverted U-shape. According to the coefficient of the regression model, appointing independent directors above $64 \%$ decrease the bank performance. This result is consistent with the argument made by Adam and Ferreira (2007) that external directors are better monitors of management, but an excessive proportion of independent directors will reduce the effectiveness of the advisory role of the board as it prevents executive directors with firm specific knowledge joining the board. Supporting this argument, Andres and Vallelado (2008) found an inverted U-shaped relation between the proportion of outsiders and firm performance, i.e. putting more external directors creates more firm value, but when reaching a higher proportion of external directors, Tobin Q starts to diminish. Therefore, it is important to realise that results contradict the current proposition that more independence is always better for firm performance. This finding is important for policy makers in setting corporate governance regulations regarding board composition. 
Table 5-6: Non-linear relationship between proportion of independent directors and firm performance

\begin{tabular}{lcccc}
\hline \hline & $(1)$ & $(2)$ & $(3)$ & $(4)$ \\
VARIABLES & ROAA & NIM & Q & SR \\
\hline LnBS & $1.439 * * *$ & $0.044 * * *$ & 0.024 & 0.001 \\
& $(0.249)$ & $(0.007)$ & $(0.029)$ & $(0.001)$ \\
IND & $\mathbf{1 1 . 2 2 3 * * *}$ & $\mathbf{0 . 3 2 9 * * *}$ & 0.170 & 0.006 \\
& $\mathbf{( 1 . 8 9 9 )}$ & $\mathbf{( 0 . 0 5 7 )}$ & $(0.173)$ & $(0.007)$ \\
IND sq & $\mathbf{- 8 . 7 9 6 * * *}$ & $\mathbf{- 0 . 2 5 7 * * *}$ & -0.146 & -0.004 \\
& $\mathbf{( 1 . 5 9 2 )}$ & $\mathbf{( 0 . 0 4 8 )}$ & $(0.143)$ & $(0.006)$ \\
Female & -0.368 & -0.011 & $-0.146^{* *}$ & $-0.005^{*}$ \\
& $(0.860)$ & $(0.026)$ & $(0.071)$ & $(0.003)$ \\
TA & -0.000 & -0.000 & 0.000 & -0.000 \\
& $(0.001)$ & $(0.000)$ & $(0.000)$ & $(0.000)$ \\
CAPITAL & $4.610 * * *$ & $0.129 * *$ & $0.342 * *$ & -0.007 \\
& $(1.753)$ & $(0.053)$ & $(0.152)$ & $(0.006)$ \\
MERGER & 0.061 & 0.003 & 0.009 & 0.000 \\
& $(0.145)$ & $(0.004)$ & $(0.012)$ & $(0.001)$ \\
LnGDP & -0.122 & 0.006 & $0.292^{* * *}$ & $0.007 * *$ \\
Constant & $(0.856)$ & $(0.026)$ & $(0.071)$ & $(0.003)$ \\
& -3.821 & -0.353 & $-7.037 * * *$ & $-0.193 * *$ \\
Observations & $(23.210)$ & $(0.698)$ & $(1.914)$ & $(0.079)$ \\
R-squared & 270 & 270 & 268 & 258 \\
Number of banks & 0.377 & 0.374 & 0.189 & 0.287 \\
Firm fixed-effects & 45 & 45 & 45 & 45 \\
Year dummies & Yes & Yes & Yes & Yes \\
F test(P value) & 0.000 & Yes & Yes & Yes \\
\hline & & 0.000 & 0.000 & 0.000 \\
\hline
\end{tabular}

Standard errors in parentheses

$$
\text { *** } \mathrm{p}<0.01, * * \mathrm{p}<0.05, * \mathrm{p}<0.1
$$

\section{Gender diversity and bank performance}

As represented in Table 5.4 above, the proportion of female directors is statistically significant and has a negative relationship on bank performance when performance is proxied by Tobin $\mathrm{Q}$ and stock return. The results are contrary to $\mathrm{H}_{5}$, which expects that female directors have a positive effect on bank performance. In the first instance when using pooled OLS, the correlation appears to be positive but when controlled for firm fixed effect to address the issue of unobserved heterogeneity the correlation reversed. This implies that the positive correlation between the proportion of female directors and bank performance in the pooled OLS regression is driven by omitted firm specific factors. The result of the study is consistent with the findings of Adam and Ferreira (2009), that female directors have an overall negative effect 
on firm performance because too much board monitoring has a detrimental effect on the firm value. Also, female directors are considered to be risk averse and market may perceive appointing female directors negatively and lead to lower financial performance when the performance is measured by market-based measures such Tobin Q and stock return.

But the above findings contradict the findings of similar studies, which found that there is a positive correlation between the proportion of female directors and firm performance (Campbell \& Minguez-Vera, 2008; Pathan \& Faff, 2013; Farag \& Mallin, 2017). They argue that gender diversity improves firm performance, consistent with the resource dependency theory and human capital theory.

To test the presence of a nonlinear relationship, the squared term of female directors was included in the model. As represented in Table 5.7, it finds that there is a U-shape relationship and appointing a female director above 34\% increases the bank performance when performance is proxied by stock returns. These findings are consistent with the critical mass theory presented by Kanter (1977) that until a certain threshold of female directors are appointed to the board, abilities and the skills a female director brings to the board is undervalued. This finding supports the introduction of gender quotas that mandated the firms to appoint a certain threshold of female directors to the board. Similar to the critical mass theory, the above findings also can be linked with the social psychological theory of minority status. i.e., when women are the minority group, they do not have enough power to exert influence and inclusion of female directors does not give a positive effect. But when there is a female representation of more than $1 / 3$ on the board, they have the power to exert influence and the firm will be able to obtain the benefit of diversity. 
Table 5-7: The non-linear relationship of proportion of female directors and financial performance

\begin{tabular}{|c|c|c|c|c|}
\hline VARIABLES & $\begin{array}{c}(1) \\
\text { ROAA } \\
\end{array}$ & $\begin{array}{c}(2) \\
\text { NIM } \\
\end{array}$ & $\begin{array}{l}\text { (3) } \\
\mathrm{Q}\end{array}$ & $\begin{array}{l}(4) \\
\text { SR } \\
\end{array}$ \\
\hline LnBS & $\begin{array}{c}1.731 \text { *** } \\
(0.263)\end{array}$ & $\begin{array}{c}0.052^{* * *} \\
(0.008)\end{array}$ & $\begin{array}{c}0.023 \\
(0.029)\end{array}$ & $\begin{array}{c}0.001 \\
(0.001)\end{array}$ \\
\hline IND & $\begin{array}{l}1.002 * * \\
(0.456)\end{array}$ & $\begin{array}{c}0.030^{* *} \\
(0.014)\end{array}$ & $\begin{array}{l}-0.003 \\
(0.036)\end{array}$ & $\begin{array}{c}0.002 \\
(0.002)\end{array}$ \\
\hline Female & $\begin{array}{l}1.058 \\
(1.965)\end{array}$ & $\begin{array}{c}0.042 \\
(0.059)\end{array}$ & $\begin{array}{l}-0.180 \\
(0.152)\end{array}$ & $\begin{array}{c}-0.014 * * \\
(0.006)\end{array}$ \\
\hline Female sq & $\begin{array}{l}-1.482 \\
(4.059)\end{array}$ & $\begin{array}{l}-0.068 \\
(0.122)\end{array}$ & $\begin{array}{c}0.109 \\
(0.314)\end{array}$ & $\begin{array}{l}0.020^{*} \\
(0.013)\end{array}$ \\
\hline TA & $\begin{array}{l}0.000 \\
(0.001)\end{array}$ & $\begin{array}{l}0.000 \\
(0.000)\end{array}$ & $\begin{array}{c}0.000 \\
(0.000)\end{array}$ & $\begin{array}{l}-0.000 \\
(0.000)\end{array}$ \\
\hline CAPITAL & $\begin{array}{c}5.201 * * * \\
(1.872)\end{array}$ & $\begin{array}{c}0.147^{* * *} \\
(0.056)\end{array}$ & $\begin{array}{c}0.331^{* *} \\
(0.152)\end{array}$ & $\begin{array}{l}-0.007 \\
(0.006)\end{array}$ \\
\hline MERGER & $\begin{array}{c}0.023 \\
(0.155)\end{array}$ & $\begin{array}{c}0.002 \\
(0.005)\end{array}$ & $\begin{array}{c}0.008 \\
(0.012)\end{array}$ & $\begin{array}{c}0.000 \\
(0.001)\end{array}$ \\
\hline LnGDP & $\begin{array}{l}-0.191 \\
(0.927)\end{array}$ & $\begin{array}{c}0.005 \\
(0.028)\end{array}$ & $\begin{array}{c}0.287 * * * \\
(0.072)\end{array}$ & $\begin{array}{c}0.006^{* *} \\
(0.003)\end{array}$ \\
\hline Constant & $\begin{array}{c}-0.888 \\
(25.152)\end{array}$ & $\begin{array}{l}-0.293 \\
(0.754)\end{array}$ & $\begin{array}{c}-6.841 * * * \\
(1.944)\end{array}$ & $\begin{array}{c}-0.169 * * \\
(0.080)\end{array}$ \\
\hline Observations & 270 & 270 & 268 & 258 \\
\hline R-squared & 0.288 & 0.289 & 0.185 & 0.294 \\
\hline Number of banks & 45 & 45 & 45 & 45 \\
\hline Firm fixed-effects & Yes & Yes & Yes & Yes \\
\hline Year dummies & Yes & Yes & Yes & Yes \\
\hline $\mathrm{F}$ test $(\mathrm{P}$ value $)$ & 0.000 & 0.000 & 0.000 & 0.000 \\
\hline
\end{tabular}

Standard errors in parentheses *** $\mathrm{p}<0.01,{ }^{* *} \mathrm{p}<0.05,{ }^{*} \mathrm{p}<0.1$

The above findings are consistent with Lang (1986), Arrow (1998), Putnam (2007) and O’Reily et al. (1989). Also, Farag and Mallin (2017) found that in the management boards the relationship is U-shaped and appointing female directors beyond a critical mass of $27 \%$ has a positive impact on financial performance. On the contrary, using a sample of banks with unitary boards in the European region, they further find that the relationship between the proportion of female directors and firm performance is nonlinear and has an inverted U-shape, i.e., appointing above $21 \%$ of female directors decreases the firm performance.

It is believed that the use of the econometric method is the reason behind the contradictory results. The study of Farag and Mallin (2017) used a two-step system GMM to control all sources of endogeneity. Therefore, the results of this study may be biased because it did not address the econometric problem of endogeneity in full. This will be further discussed in the section on limitations of the study. 
As represented in Table 5.4 above, the estimated coefficient of other control variables also has significant relationships. Tier 1 capital adequacy ratio has a statistically significant positive impact on the bank performance. It implies that well-capitalised banks perform better. This is consistent with the findings of Pathan and Faff (2013) in their study. Also, it shows that the natural logarithm of GDP has a positive and significant relationship when performance is proxied by Tobin Q and stock return, i.e., when the economy is growing, bank performance tends to be better.

\subsection{Limitations of the study}

The main limitation of this study is the use of the econometric method. As stated by Wintoki et al. (2012), the use of fixed effect estimation can control for one source of endogeneity, i.e., the unobserved heterogeneity. But it ignores the problem arising from reverse causality, that current values of board structure variables are a function of past performance. Ignoring reverse causality results in biased estimates and to control it the two-step system GMM need to be used, as used in other studies. Also, another limitation of this study is the use of the sample period of 6 years, which includes 270 bank-year observations. But it is recommended to use a longer sample period as governance variables do not significantly change over a small-time period and especially when testing the non-linear relationships, it is recommended to use much longer sample period. Many studies used much longer sample periods. ${ }^{8}$ Moreover, the contribution of this study towards the formulation of policies may have been further extended by incorporating the impact of variables such as knowledge, skills and experience of BODs to bank performance, and the specific contribution of board committees to bank performance.

\section{Discussion and conclusion}

This study examined whether the board structure (board size, board composition and gender diversity) in banks affects financial performance by using a sample of 45 banks from 10 countries in the European region during the period from 2010 - 2015. Since the importance of corporate governance in banks came to light after the global financial crisis, it is necessary to investigate how corporate governance practices, especially board characteristics, affect the financial performance of banks. In the EU, the corporate governance regulations vary based on the national codes of corporate governance in each country. Therefore, the findings of this study can contribute to the current action plan of the European Commission in developing corporate governance practices among the EU member states.

\footnotetext{
${ }^{8}$ Adam and Mehran (2012) used a period of 34 years, Pathan and Faff (2013) used 14 years, and Andre and Vallelado (2008) used 10 years in their respective studies.
} 
The study used the firm fixed effect with year dummies as the primary estimation technique to control for unobserved heterogeneity and used pooled OLS as an alternative estimation technique.

Both pooled OLS and fixed effect estimation results show that the board size is positively related to the performance, as banks benefit from a larger board due to the complexity of its operations. However, the results support the view that excessively larger boards are problematic, which shows an inverted U-shape relationship between board size and bank performance when tested for the nonlinear relationship. At the time when the number of directors reached above 19 and 28 in pooled OLS and fixed effect estimation, respectively, the bank's performance started to decrease. This finding is important to policy makers as well as individual institutions in setting up the maximum threshold for the number of directors.

Empirical evidence shows a positive relationship between the proportion of independent directors and the bank performance supporting the view that independent directors are better monitors of the banks. However, it is important to have an appropriate mix between internal directors who are better with firm specific knowledge for the advisory roles and external directors who are better at monitoring. Supporting the above view, results of the fixed effect estimation show that there is an inverted U-shape relation, and thereby, appointing independent directors above $64 \%$ will decrease the firm's performance.

Furthermore, the study found a negative relationship between the proportion of female directors and the firm's performance. This supports the argument that female directors are more risk averse than their male counterparts and too much monitoring has a detrimental effect, and hence, it affects bank financial performance negatively. But interestingly when accounting for the nonlinear relationship of the proportion of female directors, this study finds that appointing female directors above 34\% increases bank performance. This finding is consistent with the view of the critical mass theory that until a certain minimum threshold is appointed to the board, the abilities and skills of the female directors are undervalued.

The findings of this study support the initial view of the researcher that the board characteristics are an important determinant affecting bank's financial performance. The findings of this study give valuable insights to the policy makers in setting corporate governance regulations. For instance, the board of directors provide monitoring and advisory roles to improve bank governance, however, beyond a certain limit, excessively larger boards will be problematic. Also, it is important to achieve the optimal combination of executive and non-executive directors, as this balance is important to create effective boards rather than excessively independent boards. Therefore, it might be important to set a maximum limit on the board size and the proportion of independent directors for the banking sector. Furthermore, the study supports various initiatives of policy makers to introduce gender quotas. Due to the interesting results of the influence of a critical mass of female directors, policy makers should take this into account when imposing gender quotas. 
In conclusion, board characteristics play an important role in a bank's corporate governance mechanism. Thus, a good corporate governance system is beneficial not only to bank performance but also to the efficient functioning of the entire economic system.

\section{References}

Adams, R., and Ferreira, D. "A Theory of Friendly Board". The Journal of Finance, vol 62, 2007, pp.217-250.

Adams, R., and Ferreira, D. "Women in the boardroom and their impact on governance and performance". Journal of Financial Economics, vol 94, no.2, 2009, pp.291-309.

Adams, R., and Mehran, H. "Bank board structure and performance: Evidence for large bank holding companies”. Journal of Financial Intermediation, vol 21, no.2, 2012, pp.243-267.

Aebi, V., Sabato, G. and Schmid, M. "Risk management, corporate governance, and bank performance in the financial crisis". Journal of Banking \& Finance, vol 36, no.12, 2012, pp.3213-3226.

Anderson, R.C., Mansi, S., Reeb, D.M. "Board characteristics, accounting report integrity, and the cost of debt”. Journal of Accounting and Economics, vol 37, 2004, pp.315-342.

Andres, P., and Vallelado, E. "Corporate governance in banking: The role of the board of directors". Journal of Banking \& Finance, vol 32, no. 12, 2008, pp.2570-2580.

Arrow, K. "What Has Economics to Say About Racial Discrimination?". Journal of Economic Perspectives, vol 12, no. 2, 1998, pp.91-100.

Ashbaugh-Skaife, H., Collins, D.W., LaFond, R., "The effects of corporate governance on firms' credit ratings". Journal of Accounting and Economics, vol 42, 2006, pp. 203-243.

Basel Committee on Banking Supervision. "Corporate Governance Principles for Banks”. [online] Basel: Bank for International Settlements, 2018. Available at: http://www.bis.org/bcbs/publ/d328.pdf [Accessed 22 Jul. 2017].

Becker, G. Human Capital. Chicago, IL: University of Chicago, 1964.

Berger, A., Kick, T., and Schaeck, K. "Executive board composition and bank risk taking". Journal of Corporate Finance, vol 28, 2014. pp.48-65.

Bhatt, R. and Bhattacharya, S. "Do Board Characteristics Impact Firm Performance? An Agency and Resource Dependency Theory Perspective". Asia-Pacific Journal of Management Research and Innovation, vol 11, no.4, 2015, pp.274-287. 
Boone, A., Casares Field, L., Karpoff, J. and Raheja, C. "The determinants of corporate board size and composition: An empirical analysis". Journal of Financial Economics, vol 85, no.1, 2007, pp.66-101.

Brooks, C. Introductory Econometrics for Finance. Cambridge University Press New York, 2008.

Campbell, K., and Mínguez-Vera, A. "Gender Diversity in the Boardroom and Firm Financial Performance”. Journal of Business Ethics, vol 83, no.3, 2007, pp.435-451.

Caprio, G., Levine, R., "Corporate governance of banks: concepts and international observations". Paper presented at the Global Corporate Governance Forum Research Network Meeting, 2002.

Caprio, G., Laeven, L. and Levine, R. "Governance and bank valuation. Journal of Financial Intermediation”. Vol 16, no. 4, 2007, pp.584-617.

Carter, D., Simkins, B. and Simpson, W. "Corporate Governance, Board Diversity, and Firm Value”. The Financial Review, vol 38, no. 1, 2003, pp.33-53.

Carter, D., D'Souza, F., Simkins, B. and Simpson, W. "The Gender and Ethnic Diversity of US Boards and Board Committees and Firm Financial Performance". Corporate Governance: An International Review, vol 18, no. 5, 2010, pp.396-414.

Coles, J., Daniel, N. and Naveen, L. Boards: "Does one size fit all”. Journal of Financial Economics, vol 87, no.2, 2008, pp.329-356.

Corporate Governance Committee-Borsa Italiana, Corporate Governance Code. [Online] Borsa Italiana, 2015. Available at:

http://www.borsaitaliana.it/borsaitaliana/regolamenti/corporategovernance/ corporategovernance.en.html [Accessed 17 Aug. 2017].

Dalton, D., Daily, C., Johnson, J. and Ellstrand, A. "Number of Directors and Financial Performance: A Meta-Analysis". Academy of Management Journal, vol 42, no.6, 1999, pp.674-686.

de Cabo, R., Gimeno, R. and Escot, L. "Disentangling Discrimination on Spanish Boards of Directors". Corporate Governance: An International Review, vol 19, no.1, 2010, pp.77-95.

Directorate-Generale for Justice and Consumers. "Gender balance on corporate boards. Europe is cracking the glass ceiling”. European Commission, 2016.

Duchin, R., Matsusaka, J. and Ozbas, O. "When are outside directors effective?". Journal of Financial Economics, vol 96, no. 2, 2010, pp.195-214.

Eagly, A., Carli, L., “The female leadership advantage: an evaluation of the evidence". The Leadership Quarterly, vol 14, 2003, pp.807-834. 
Eisenberg, T., Sundgren, S. and Wells, M. "Larger board size and decreasing firm value in small firms". Journal of Financial Economics, vol 48, 1998, pp.35-54.

European Central Bank, Report on Financial Structures. [Online] Brussels: European Central Bank., 2016, Available at:

https://www.ecb.europa.eu/pub/pdf/other/reportonfinancialstructures201610.en.pdf [Accessed 26 Jul. 2017].

European Commission, National Fact Sheet-Gender Balance in Boards. [Online] Brussels:

European Commission, 2013. Available at: http://ec.europa.eu/justice/genderequality/files/womenonboards/womenonboards-factsheet-uk_en.pdf [Accessed 22 Jul. 2017].

European Commission, Gender Balance on Corporate Boards: Europe is cracking the glass ceiling.

[Online] Brussels: European Commission, 2015. Available at:

http://ec.europa.eu/justice/gender-

equality/files/womenonboards/factsheet_women_on_boards_web_2015-10_en.pdf [Accessed 23 Jul. 2017].

Fama, E. and Jensen, M. "Separation of ownership and control". Journal of Law and Economics, vol 26, 1983, pp.301-325.

Fama, E.F., What's different about bank? Journal of Monetary Economics, vol 15, 1985, pp.29-39

Farag, H. and Mallin, C. "Board diversity and financial fragility: Evidence from European banks”. International Review of Financial Analysis, vol 49, 2017, pp.98-112.

Farrell, K. and Hersch, P. "Additions to corporate boards: the effect of gender". Journal of Corporate Finance, vol 11, no. 1-2, 2005, pp.85-106.

Financial Reporting Council, "UK Corporate Governance Code - April 2016. London: FRC, 2016.

Francis, B., Hasan, I., Wu, Q., "Do Corporate Boards Affect Firm Performance? New Evidence from the Financial Crisis”. SSRN Electronic Journal, 2012.

Francoeur, C., Labelle, R. and Sinclair-Desgagné, B., "Gender Diversity in Corporate Governance and Top Management”. Journal of Business Ethics, vol 81, no.1, 2007, pp.8395.

Graham, J., Hazarika, S. and Narasimhan, K., "Corporate Governance, Debt, and Investment Policy during the Great Depression”. Management Science, vol 57, no.12, 2011, pp.2083-2100.

Gul, F., Srinidhi, B. and Ng, A. "Does board gender diversity improve the informativeness of stock prices?". Journal of Accounting and Economics, vol 51, no.3, 2011, pp.314-338. 
Harris, M. and Raviv, A. "A Theory of Board Control and Size". Review of Financial Studies, vol 21, no.4, 2006, pp.1797-1832.

Heidrick and Struggles Inc. Towards Dynamic Governance 2014: European Corporate Governance Report. [Online] Chicago: Heidrick \& Struggles, 2014, Available at:http://www.heidrick.com/ /media/Publications\% 20and\%20Reports/EuropeanCorporate-Governance-Report-2014-Towards-Dynamic-Governance.pdf [Accessed 22 Jul. 2017].

Hermalin, B. E., \& Weisbach, M. S., "The determinants of board composition". The Rand Journal of Economics, vol 19, 1998, pp. 589-606.

Hermalin, B.E., Weisbach, M.S., "Boards of directors as an endogenously determined institution: a survey of the economic literature". FRBNY Economic Policy Review, vol 9, 2003, pp. 7-26.

Hillman, A., Cannella, A. and Paetzold, R., “The Resource Dependence Role of Corporate Directors: Strategic Adaptation of Board Composition in Response to Environmental Change". Journal of Management Studies, vol 37, no.2, 2000, pp.235-256.

Hillman, A., Cannella, A. and Harris, I. "Women and Racial Minorities in the Boardroom: How Do Directors Differ?”. Journal of Management, vol 28, no. 6, 2002, pp.747-763.

Hillman, A. and Dalziel, T. "Boards of Directors and Firm Performance: Integrating Agency and Resource Dependence Perspectives”. Academy of Management Review, vol 28, no. 3, 2003, pp.383-396.

Houston, J., Lin, C. and Ma, Y. "Regulatory Arbitrage and International Bank Flows". The Journal of Finance, vol 67, no. 5, 2012, pp.1845-1895.

III, C., Caldwell, D. and Barnett, W. "Work Group Demography, Social Integration, and Turnover”. Administrative Science Quarterly, vol 34, no. 1, 1989, p.21.

International Finance Corporation, A Guide to Corporate Governance Practices in the European Union. [Online] Washington: World Bank, 2015, Available at: http://www.ifc.org/wps/wcm/connect/c44d6d0047b7597bb7d9f7299ede9589/CG_ Practices_in_EU_Guide.pdf?MOD=AJPERES [Accessed 22 Jul. 2017].

Jensen, M. "The Modern Industrial Revolution, Exit, and the Failure of Internal Control Systems". The Journal of Finance, vol 48, no. 3, 1993, p.831.

Joecks, J., Pull, K. and Vetter, K. "Gender Diversity in the Boardroom and Firm Performance: What Exactly Constitutes a “Critical Mass?”. Journal of Business Ethics, vol 118, no.1, 2012, pp.61-72. 
Kanter, R. "Some Effects of Proportions on Group Life: Skewed Sex Ratios and Responses to Token Women”. American Journal of Sociology, vol 82, no.5, 1977, pp.965-990.

Kim, D. and Starks, L. "Gender Diversity on Corporate Boards: Do Women Contribute Unique Skills?”. American Economic Review, vol 106, no.5, 2016, pp.267-271.

Laeven, L. and Levine, R. "Bank governance, regulation and risk taking". Journal of Financial Economics, vol 93, no.2, 2009, pp. 259-275.

Lang, K., “A Language Theory of Discrimination". The Quarterly Journal of Economics, vol 101, no.2, 1986, p.363.

Levine, R., "The corporate governance of the banks: A concise discussion of concepts and evidence". Working Paper, World Bank Policy Research, 2004.

Liang, Q., Xu, P. and Jiraporn, P. "Board characteristics and Chinese bank performance". Journal of Banking \& Finance, vol 37, no. 8, 2013, pp.2953-2968.

Lindquist., K., 'Banks' buffer capital: How important is risk, Journal of International Money and Finance" vol 23, 2004, pp. 493-513

Linck, J.S., Netter, J.M., Yang, T., “The effects and unintended consequences of the Sarbanes-Oxley Act on the supply and demand for directors". Review of Financial Studies, vol 22, 2009, pp.3287-3328

Lipton, M. and Lorsch, J. “A modest proposal for Improved Corporate Governance”. Business Lanyer, Vol 48, no.1, 1992, pp.59-78.

Macey, J.R., O’Hara, M., “The corporate governance of banks”. FRBNY Economic Policy Review, vol 9, 2003, pp.91-107.

Mallin, C. Corporate governance. Oxford: Oxford University Press, 2004.

Mateos de Cabo, R., Gimeno, R. and Nieto, M. "Gender Diversity on European Banks' Boards of Directors”. Journal of Business Ethics, vol 109, no. 2, 2011, pp.145-162.

Mishkin, F. The Economics of Money, Banking and Financial Markets. 11 th Ed, Essex: Pearson, 2016, pp.261-273, 313-334.

Mishra, C. and Nielsen, J. "Board Independence and Compensation Policies in Large Bank Holding Companies". Financial Management, vol 29, no.3, 2000. p.51.

Monks, R. A. G. \& Minow, N. Corporate governance, 3rd edn. Madden, MA: Blackwell Publishing Ltd, 2004.

Muller-Kahle, M. and Lewellyn, K. "Did Board Configuration Matter? The Case of US Subprime Lenders". Corporate Governance: An International Review, vol 19, no.5), 2011, pp.405-417. 
O'Reilly, C. A., III, Caldwell, D. F., \& Barnett, W. P. "Workgroup demography, social integration, and turnover, Administrative Science Quarterly, vol 34, 1989, pp.21-37.

O’Sullivan, J., Mamun, A. and Hassan, M. "The relationship between board characteristics and performance of bank holding companies: before and during the financial crisis”, Journal of Economics and Finance, vol 40, no. 3, 2015, pp.438-471.

Pathan, S. "Strong boards, CEO power and bank risk-taking". Journal of Banking \& Finance, vol 33, no. 7, 2009, pp.1340-1350.

Pathan, S. and Faff, R. "Does board structure in banks really affect their performance?” Journal of Banking \& Finance, vol 37, no. 5, 2013, pp.1573-1589.

Pfeffer, J. and Salancik, G. "The external control of organizations: a resource dependence perspective". New York: Harper \& Row, 2003.

Prudential Regulatory Authority, Supervisory Statement: Corporate governance: Board responsibilities. [online] London: Bank of England, 2016, Available at: http://www.bankofengland.co.uk/pra/Documents/publications/ss/2016/ss516.pdf [Accessed 22 Jul. 2017].

Putnam, R. "E Pluribus Unum: Diversity and Community in the Twenty-first Century The 2006 Johan Skytte Prize Lecture”. Scandinavian Political Studies, vol 30, no.2, 2007. pp.137-174.

Randoy, T., Thomsen, S. and Oxelheim, L. "A Nordic perspective on corporate board diversity”. Nordic innovation centre project. Norway: Agder University College, 2006.

Robinson, G. and Dechant, K. "Building a business case for diversity". Academy of Management Perspectives, vol 11, no.3, 1997, pp.21-31.

Rose, C. "Does female board representation influence firm performance? The Danish evidence". Corporate Governance: An International Review, vol 15, no.2, 2007, pp.404-413.

Salim, R., Arjomandi, A. and Seufert, J. "Does corporate governance affect Australian banks' performance?” Journal of International Financial Markets, Institutions and Money, vol 43, 2016, pp.113-125.

Subrahmanyam, V., Rangan, N., Rosenstein, S., "The role of outside directors in bank acquisitions", Financial Management, vol 26, 1997, pp.23-36.

Terjesen, S., Sealy, R. and Singh, V. "Women Directors on Corporate Boards: A Review and Research Agenda". Corporate Governance: An International Review, vol 17, no.3, 2009, pp.320-337. 
Weisbach, M. and Hermalin, B. "Boards of Directors as an Endogenously Determined Institution: A Survey of the Economic Literature". Working papers- Yale School of Management's Economic Research Network, 2010.

Westphal, J. and Milton, L. "How Experience and Network Ties Affect the Influence of Demographic Minorities on Corporate Boards". Administrative Science Quarterly, vol 45, 2000, pp.366-398.

Wintoki, M., Linck, J. and Netter, J. "Endogeneity and the dynamics of internal corporate governance”. Journal of Financial Economics, vol 105, no.3, 2012, pp.581-606.

Wooldridge, J. M. "Econometric analysis of cross section and panel data". Cambridge: The MIT Press, 2002.

Yermack, D. "Higher market valuation of companies with a small board of directors". Journal of Financial Economics, vol 40, no.2, 1996, pp.185-211. 


\section{Appendices}

Table -A1: Summary of academic literature

\begin{tabular}{|c|c|c|c|c|}
\hline & Author \& Year & $\begin{array}{l}\text { Sample } \\
\text { Period }\end{array}$ & Country & $\begin{array}{l}\text { Empirical } \\
\text { Results }\end{array}$ \\
\hline \multirow[t]{9}{*}{$\begin{array}{c}\text { Board Size and } \\
\text { Performance }\end{array}$} & $\begin{array}{l}\text { Adam and } \\
\text { Mehran (2012) }\end{array}$ & 1986-1996 & $\begin{array}{l}35 \text { listed Bank } \\
\text { Holding } \\
\text { Companies of } \\
\text { USA }\end{array}$ & Positive \\
\hline & $\begin{array}{l}\text { O’Sullivan, } \\
\text { Mamun \& } \\
\text { Hassan (2016) }\end{array}$ & $\begin{array}{l}1999 \text { to } \\
2009 .\end{array}$ & $\begin{array}{l}\text { largest } 150 \text { U.S. } \\
\text { Bank Holding } \\
\text { Companies }\end{array}$ & Positive \\
\hline & $\begin{array}{l}\text { Pathan and Faff } \\
(2013)\end{array}$ & 1997-2011 & $\begin{array}{l}212 \text { US bank } \\
\text { holding } \\
\text { companies }\end{array}$ & Negative \\
\hline & $\begin{array}{l}\text { Liang, } \mathrm{Xu} \text { and } \\
\text { Jiraporn (2013) }\end{array}$ & $\begin{array}{l}2003 \text { to } \\
2010\end{array}$ & $\begin{array}{l}\text { top } 50 \text { Chinese } \\
\text { banks }\end{array}$ & Negative \\
\hline & Yermach, 1996 & $\begin{array}{l}1984- \\
1991 .\end{array}$ & $\begin{array}{l}452 \text { large U.S. } \\
\text { industrial } \\
\text { corporations }\end{array}$ & Negative \\
\hline & $\begin{array}{l}\text { Eisenberg et al } \\
1998\end{array}$ & 1992-1994 & $\begin{array}{l}\text { Small and midsize } \\
\text { Finnish firms }\end{array}$ & Negative \\
\hline & $\begin{array}{l}\text { Hermalin and } \\
\text { Weisbach, } 2013\end{array}$ & 1971-1983 & $\begin{array}{l}322 \text { US listed } \\
\text { companies }\end{array}$ & Negative \\
\hline & $\begin{array}{l}\text { Andres \& } \\
\text { Vallelado (2008) }\end{array}$ & $1995-2005$ & $\begin{array}{l}69 \text { large } \\
\text { commercial } \\
\text { banks from six } \\
\text { OECD countries }\end{array}$ & $\begin{array}{l}\text { Inverted U shape } \\
\text { relationship }\end{array}$ \\
\hline & $\begin{array}{l}\text { Coles et al. } \\
\text { (2008) }\end{array}$ & 1992-2001 & USA firms & $\begin{array}{l}\text { Inverted U shape } \\
\text { relationship }\end{array}$ \\
\hline $\begin{array}{c}\text { Board } \\
\text { Independence } \\
\text { and }\end{array}$ & $\begin{array}{l}\text { Mishra and } \\
\text { Nielsen,2000 }\end{array}$ & 1990 & $\begin{array}{l}89 \text { US Bank } \\
\text { Holding } \\
\text { companies }\end{array}$ & Positive \\
\hline \multirow[t]{2}{*}{ Performance } & $\begin{array}{l}\text { Anderson, } \\
\text { etal.,2004 }\end{array}$ & 1993-1998 & S\&P 500 firms & Positive \\
\hline & $\begin{array}{l}\text { Andres \& } \\
\text { Vallelado (2008) }\end{array}$ & $1995-2005$ & $\begin{array}{l}69 \text { large } \\
\text { commercial } \\
\text { banks from six }\end{array}$ & $\begin{array}{l}\text { Inverted U shape } \\
\text { relationship }\end{array}$ \\
\hline
\end{tabular}




\begin{tabular}{|c|c|c|c|c|}
\hline & Author \& Year & $\begin{array}{l}\text { Sample } \\
\text { Period }\end{array}$ & Country & $\begin{array}{l}\text { Empirical } \\
\text { Results }\end{array}$ \\
\hline & $\begin{array}{l}\text { Adam and } \\
\text { Mehran (2012) }\end{array}$ & 1986-1996 & $\begin{array}{l}35 \text { listed Bank } \\
\text { Holding } \\
\text { Companies of } \\
\text { USA }\end{array}$ & $\begin{array}{l}\text { Not related to } \\
\text { performance }\end{array}$ \\
\hline & $\begin{array}{l}\text { Pathan and Faff } \\
(2013)\end{array}$ & $1997-2011$ & $\begin{array}{l}212 \text { US bank } \\
\text { holding } \\
\text { companies }\end{array}$ & Negative \\
\hline \multirow{8}{*}{$\begin{array}{l}\text { Gender } \\
\text { Diversity and } \\
\text { Performance }\end{array}$} & $\begin{array}{l}\text { Adam and } \\
\text { Ferreira (2009) }\end{array}$ & 1996-2003. & $\begin{array}{l}\text { S\&P } 500 \\
\text { companies }\end{array}$ & Negative \\
\hline & $\begin{array}{l}\text { Pathan and Faff } \\
\text { (2013) }\end{array}$ & $1997-2011$ & $\begin{array}{l}212 \text { US bank } \\
\text { holding } \\
\text { companies }\end{array}$ & $\begin{array}{l}\text { Improves bank } \\
\text { performance in } \\
\text { pre-sox period } \\
\text { but it decreases in } \\
\text { post-sox and } \\
\text { crisis periods }\end{array}$ \\
\hline & $\begin{array}{l}\text { Carter et al. } \\
(2010)\end{array}$ & 1998-2002 & $\begin{array}{l}\text { S\&P } 500 \\
\text { companies }\end{array}$ & No relationship \\
\hline & $\begin{array}{l}\text { Campbell and } \\
\text { Minguez-Vera } \\
(2008)\end{array}$ & $1995-2000$ & $\begin{array}{l}\text { Listed non- } \\
\text { financial firms in } \\
\text { Spain }\end{array}$ & $\begin{array}{l}\text { Positive } \\
\text { relationship }\end{array}$ \\
\hline & $\begin{array}{l}\text { Carter et al } \\
(2003)\end{array}$ & $1995-2000$ & $\begin{array}{l}\text { Fortune } 1000 \\
\text { firms }\end{array}$ & $\begin{array}{l}\text { Positive } \\
\text { relationship }\end{array}$ \\
\hline & $\begin{array}{l}\text { Kim and Starks } \\
\text { (2016) }\end{array}$ & 2011-2013 & $\begin{array}{l}\text { S\&P Small cap } \\
600\end{array}$ & $\begin{array}{l}\text { Positive } \\
\text { relationship }\end{array}$ \\
\hline & $\begin{array}{l}\text { Joecks, Pull and } \\
\text { Vetter (2012) }\end{array}$ & 1988-1992 & $\begin{array}{l}\text { The US listed } \\
\text { companies }\end{array}$ & $\begin{array}{l}\text { U-shaped } \\
\text { relationship }\end{array}$ \\
\hline & $\begin{array}{l}\text { Farag and Mallin } \\
(2017)\end{array}$ & 2004-2012 & $\begin{array}{l}99 \text { European } \\
\text { banks }\end{array}$ & $\begin{array}{l}\text { An inverted U- } \\
\text { shaped } \\
\text { relationship for } \\
\text { unitary boards } \\
\text { and U-shaped } \\
\text { relationship for } \\
\text { Management } \\
\text { boards }\end{array}$ \\
\hline
\end{tabular}

Source: Compiled by author 
Table A2: Pooled OLS results for non-linear relationship between board size and bank performance

\begin{tabular}{|c|c|c|c|c|}
\hline \multicolumn{5}{|c|}{ Non-linear relationship between Board size and Bank Performance } \\
\hline \multirow[b]{2}{*}{ VARIABLES } & \multirow{2}{*}{$\begin{array}{c}(1) \\
\text { ROAA }\end{array}$} & \multirow{2}{*}{$\begin{array}{c}(2) \\
\text { NIM }\end{array}$} & \multirow{2}{*}{$\begin{array}{l}\text { (3) } \\
\text { Q }\end{array}$} & \multirow{2}{*}{$\begin{array}{l}\text { (4) } \\
\text { SR }\end{array}$} \\
\hline & & & & \\
\hline \multirow[t]{2}{*}{ BS } & $0.247 * * *$ & $0.009 * * *$ & 0.003 & $-0.000^{*}$ \\
\hline & $(0.049)$ & $(0.002)$ & $(0.009)$ & $(0.000)$ \\
\hline \multirow[t]{2}{*}{ BS sq } & $-0.006 * * *$ & $-0.0002 * * *$ & -0.000 & $0.000^{*}$ \\
\hline & $(0.001)$ & $(0.000)$ & $(0.000)$ & $(0.000)$ \\
\hline \multirow[t]{2}{*}{ IND } & 0.368 & 0.007 & $0.118^{* * *}$ & $0.002 * * *$ \\
\hline & $(0.228)$ & $(0.007)$ & $(0.038)$ & $(0.001)$ \\
\hline \multirow[t]{2}{*}{ Female } & 0.327 & 0.002 & $0.741 * * *$ & 0.001 \\
\hline & $(0.523)$ & $(0.016)$ & $(0.086)$ & $(0.002)$ \\
\hline \multirow[t]{2}{*}{ TA } & $-0.000^{*}$ & $-0.000^{* *}$ & $-0.000 * * *$ & -0.000 \\
\hline & $(0.000)$ & $(0.000)$ & $(0.000)$ & $(0.000)$ \\
\hline \multirow{2}{*}{ CAPITAL } & $6.212^{* * *}$ & $0.156^{* * *}$ & $0.641 * *$ & 0.006 \\
\hline & $(1.383)$ & $(0.043)$ & $(0.247)$ & $(0.005)$ \\
\hline \multirow[t]{2}{*}{ MERGER } & -0.002 & 0.002 & -0.025 & 0.000 \\
\hline & $(0.134)$ & $(0.004)$ & $(0.022)$ & $(0.000)$ \\
\hline \multirow[t]{2}{*}{ LnGDP } & 0.063 & 0.001 & $-0.019 *$ & $0.001 * * *$ \\
\hline & $(0.067)$ & $(0.002)$ & $(0.011)$ & $(0.000)$ \\
\hline \multirow[t]{2}{*}{ Constant } & $-4.644 * * *$ & $-0.115^{* *}$ & $1.378^{* * *}$ & $-0.025^{* * *}$ \\
\hline & $(1.788)$ & $(0.055)$ & $(0.303)$ & $(0.006)$ \\
\hline Observations & 270 & 270 & 268 & 258 \\
\hline R-squared & 0.202 & 0.205 & 0.404 & 0.267 \\
\hline Firm fixed-effects & No & No & No & No \\
\hline Year dummies & Yes & Yes & Yes & Yes \\
\hline F test( $(\mathrm{P}$ value $)$ & 0.000 & 0.000 & 0.000 & 0.000 \\
\hline
\end{tabular}

Standard errors in parentheses $* * * \mathrm{p}<0.01,{ }^{* *} \mathrm{p}<0.05,{ }^{*} \mathrm{p}<0.1$ 
Table A3: Pooled OLS results for non-linear relationship between independent directors and bank performance

\begin{tabular}{|c|c|c|c|c|}
\hline \multicolumn{5}{|c|}{ Non-linear relation between Independent Directors and Bank Performance } \\
\hline \multirow[b]{2}{*}{ VARIABLES } & (1) & \multirow{2}{*}{$\begin{array}{c}(2) \\
\text { NIM }\end{array}$} & \multirow{2}{*}{$\begin{array}{l}(3) \\
Q\end{array}$} & \multirow{2}{*}{$\begin{array}{l}(4) \\
\text { SR }\end{array}$} \\
\hline & ROAA & & & \\
\hline \multirow[t]{2}{*}{ BS } & $0.036^{* * *}$ & $0.001 * * *$ & $-0.003 *$ & 0.000 \\
\hline & $(0.011)$ & $(0.000)$ & $(0.002)$ & $(0.000)$ \\
\hline \multirow[t]{2}{*}{ IND } & $3.562 * * *$ & $0.109 * * *$ & 0.074 & 0.004 \\
\hline & $(0.925)$ & $(0.029)$ & $(0.156)$ & $(0.003)$ \\
\hline \multirow[t]{2}{*}{ IND sq } & $-2.986 * * *$ & $-0.095 * * *$ & 0.041 & -0.001 \\
\hline & $(0.848)$ & $(0.027)$ & $(0.142)$ & $(0.003)$ \\
\hline \multirow[t]{2}{*}{ Female } & 0.861 & 0.020 & $0.743^{* * *}$ & 0.000 \\
\hline & $(0.530)$ & $(0.017)$ & $(0.087)$ & $(0.002)$ \\
\hline \multirow[t]{2}{*}{ TA } & $-0.000 * *$ & $-0.000 * *$ & $-0.000^{* * *}$ & -0.000 \\
\hline & $(0.000)$ & $(0.000)$ & $(0.000)$ & $(0.000)$ \\
\hline \multirow[t]{2}{*}{ CAPITAL } & $5.521 * * *$ & $0.132 * * *$ & $0.602 * *$ & 0.005 \\
\hline & $(1.398)$ & $(0.044)$ & $(0.241)$ & $(0.005)$ \\
\hline \multirow[t]{2}{*}{ MERGER } & 0.082 & 0.005 & -0.024 & 0.000 \\
\hline & $(0.135)$ & (0.004) & $(0.022)$ & $(0.000)$ \\
\hline \multirow[t]{2}{*}{ LnGDP } & 0.104 & 0.003 & $-0.019 *$ & $0.001 * * *$ \\
\hline & $(0.067)$ & $(0.002)$ & (0.011) & $(0.000)$ \\
\hline \multirow[t]{2}{*}{ Constant } & $-4.874 * * *$ & $-0.120 * *$ & $1.415^{* * *}$ & $-0.026 * * *$ \\
\hline & $(1.816)$ & $(0.057)$ & $(0.303)$ & $(0.006)$ \\
\hline Observations & 270 & 270 & 268 & 258 \\
\hline $\mathrm{R}$-squared & 0.181 & 0.157 & 0.403 & 0.259 \\
\hline $\begin{array}{l}\text { Firm fixed- } \\
\text { effects }\end{array}$ & No & No & No & No \\
\hline Year dummies & Yes & Yes & Yes & Yes \\
\hline F test $(\mathrm{P}$ value $)$ & 0.000 & 0.000 & 0.000 & 0.000 \\
\hline
\end{tabular}

Standard errors in parentheses

*** $\mathrm{p}<0.01,{ }^{* *} \mathrm{p}<0.05, * \mathrm{p}<0.1$ 
Table A4: Pooled OLS results for non-linear relationship between female directors an bank performance

\begin{tabular}{|c|c|c|c|c|}
\hline \multicolumn{5}{|c|}{ Non-linear relationship between female directors and bank performance } \\
\hline \multirow[b]{2}{*}{ VARIABLES } & (1) & (2) & \multirow{2}{*}{$\begin{array}{l}(3) \\
Q\end{array}$} & \multirow{2}{*}{$\begin{array}{l}(4) \\
\text { SR }\end{array}$} \\
\hline & ROAA & NIM & & \\
\hline \multirow[t]{2}{*}{ BS } & $0.035^{* * *}$ & $0.001 * * *$ & $-0.003 *$ & 0.000 \\
\hline & $(0.011)$ & $(0.000)$ & $(0.002)$ & $(0.000)$ \\
\hline \multirow[t]{2}{*}{ IND } & $0.409 *$ & 0.009 & $0.116^{* * *}$ & $0.002^{* * *}$ \\
\hline & $(0.235)$ & $(0.007)$ & $(0.038)$ & $(0.001)$ \\
\hline \multirow[t]{2}{*}{ Female } & $3.156 * *$ & $0.105^{* *}$ & 0.393 & -0.008 \\
\hline & $(1.539)$ & $(0.048)$ & $(0.250)$ & $(0.005)$ \\
\hline \multirow[t]{2}{*}{ Female sq } & $-5.425 *$ & $-0.198 * *$ & 0.755 & $0.018^{*}$ \\
\hline & (3.094) & $(0.097)$ & $(0.500)$ & $(0.010)$ \\
\hline \multirow[t]{2}{*}{ TA } & -0.000 & $-0.000^{*}$ & $-0.000 * * *$ & -0.000 \\
\hline & $(0.000)$ & $(0.000)$ & $(0.000)$ & $(0.000)$ \\
\hline \multirow[t]{2}{*}{ CAPITAL } & $5.534^{* * *}$ & $0.131 * * *$ & $0.612^{* *}$ & 0.005 \\
\hline & $(1.426)$ & $(0.045)$ & $(0.240)$ & $(0.005)$ \\
\hline \multirow[t]{2}{*}{ MERGER } & 0.065 & 0.004 & -0.024 & 0.000 \\
\hline & $(0.137)$ & (0.004) & $(0.022)$ & $(0.000)$ \\
\hline \multirow[t]{2}{*}{ LnGDP } & 0.096 & 0.002 & -0.017 & $0.001 * * *$ \\
\hline & $(0.069)$ & $(0.002)$ & (0.011) & $(0.000)$ \\
\hline \multirow[t]{2}{*}{ Constant } & $-4.168^{* *}$ & $-0.097 *$ & $1.396^{* * *}$ & $-0.027 * * *$ \\
\hline & $(1.844)$ & $(0.058)$ & $(0.299)$ & $(0.006)$ \\
\hline Observations & 270 & 270 & 268 & 258 \\
\hline R-squared & 0.151 & 0.130 & 0.408 & 0.267 \\
\hline $\begin{array}{l}\text { Firm fixed- } \\
\text { effects }\end{array}$ & No & No & No & No \\
\hline Year dummies & Yes & Yes & Yes & Yes \\
\hline $\mathrm{F}$ test $(\mathrm{P}$ value $)$ & 0.000 & 0.000 & 0.000 & 0.000 \\
\hline
\end{tabular}

Standard errors in parentheses

*** $\mathrm{p}<0.01, * * \mathrm{p}<0.05, * \mathrm{p}<0.1$ 